\title{
Understanding the Application of Raman Spectroscopy to the Detection of Traces of Life
}

\author{
Craig P. Marshall, Howell G.M. Edwards, ${ }^{2}$ and Jan Jehlicka ${ }^{3}$
}

\begin{abstract}
Investigating carbonaceous microstructures and material in Earth's oldest sedimentary rocks is an essential part of tracing the origins of life on our planet; furthermore, it is important for developing techniques to search for traces of life on other planets, for example, Mars. NASA and ESA are considering the adoption of miniaturized Raman spectrometers for inclusion in suites of analytical instrumentation to be placed on robotic landers on Mars in the near future to search for fossil or extant biomolecules. Recently, Raman spectroscopy has been used to infer a biological origin of putative carbonaceous microfossils in Early Archean rocks. However, it has been demonstrated that the spectral signature obtained from kerogen (of known biological origin) is similar to spectra obtained from many poorly ordered carbonaceous materials that arise through abiotic processes. Yet there is still confusion in the literature as to whether the Raman spectroscopy of carbonaceous materials can indeed delineate a signature of ancient life. Despite the similar nature in spectra, rigorous structural interrogation between the thermal alteration products of biological and nonbiological organic materials has not been undertaken. Therefore, we propose a new way forward by investigating the second derivative, deconvolution, and chemometrics of the carbon first-order spectra to build a database of structural parameters that may yield distinguishable characteristics between biogenic and abiogenic carbonaceous material. To place Raman spectroscopy as a technique to delineate a biological origin for samples in context, we will discuss what is currently accepted as a spectral signature for life; review Raman spectroscopy of carbonaceous material; and provide a historical overview of Raman spectroscopy applied to Archean carbonaceous materials, interpretations of the origin of the ancient carbonaceous material, and a future way forward for Raman spectroscopy. Key Words: ArcheanBiogenicity—Kerogen—Precambrian fossils—Raman spectroscopy. Astrobiology 10, 229-243.
\end{abstract}

\section{Introduction}

$\mathbf{I}_{\mathrm{n}}^{\mathrm{N}}$ NVESTIGATING CARBONACEOUS MICROSTRUCTURES and material in Earth's oldest sedimentary Archean rocks is an essential part of tracing the origins of life on our planet; furthermore, it is important for developing techniques to search for traces of life on other planets, for example, Mars. Archean cherts contain carbonaceous microstructures that resemble morphologically preserved putative microfossils. Putative microfossils have been reported in the 3.5-3.0 Ga Pilbara Supergroup, Australia (e.g., Awramik et al., 1983; Schopf, 1993; Rasmussen, 2000; Ueno et al., 2001a, 2001b), and the penecontemporaneous Swaziland Supergroup, South Africa (e.g., Knoll and Barghoorn, 1977; Walsh and Lowe, 1985; Westall et al., 2001). These reported microstructures exhibit filamentous and coccoidal morphologies that have been attributed to cyanobacteria (Awramik et al., 1983; Schopf, 1993). Often these microstructures are in a poor state of preservation and exhibit relatively simple morphologies that consequently have resulted in endless doubts about their biogenicity (e.g., Schopf and Walter, 1983; Buick, 1990). Other approaches beside morphology are required to alleviate this ambiguity. Pflug and Jaeschke-Boyer (1979) were early advocates of multiple analytical chemical approaches that addressed the physics, chemistry, and biology involved and could be applied to identify a microfossil. Hence, they coined the phrase "the best way of confirming the biogenicity of a fossil residue is by relating morphology and chemistry."

Archean cherts at best have undergone prehnite-pumpellyite to greenschist facies metamorphism, which has resulted in the degradation of biomolecules by thermal alteration, and consequently their primary spectral signatures have been destroyed (Summons and Walter, 1990). Therefore, carbon isotopic signatures on bulk carbonaceous materials and

\footnotetext{
${ }^{1}$ Department of Geology, The University of Kansas, Lawrence, Kansas, USA.

${ }^{2}$ School of Life Sciences, University of Bradford, Division of Chemical and Forensic Sciences, Bradford, UK.

${ }^{3}$ Institute of Geochemistry, Mineralogy, and Mineral Resources, Charles University in Prague, Prague, Czech Republic.
} 
microstructures have been obtained (e.g., Mojzsis et al., 1996; Rosing, 1999; Schidlowski, 2001; Ueno et al., 2001a, 2001b, $2002,2004,2006)$. However, the use of carbon isotope compositions for unambiguously assessing biological contributions to carbonaceous materials preserved in Archean rocks has come under intense scrutiny (e.g., Brasier et al., 2002, 2005; Lindsay et al., 2005; McCollom and Seewald, 2006; Marshall et al., 2007a). McCollom and Seewald (2006) recently showed that the abiotic synthesis of organic compounds $\left(\mathrm{C}_{2}-\mathrm{C}_{28}\right.$ n-alkanes $)$ under laboratory-simulated hydrothermal conditions can yield organic products depleted in ${ }^{13} \mathrm{C}$ to a degree usually diagnostic of biological isotopic fractionation $(-36 \%$ depletion in organic carbon, in the form of isotopically uniform $n$-alkanes, estimated relative to source carbon dioxide was observed), at least when overall $\mathrm{CO}_{2} / \mathrm{CO}$ reductive conversions are low. So, additional key evidence from molecular and compoundspecific isotopic patterns (Marshall et al., 2007a), as well as spectroscopic characterization, is necessary to differentiate biotic from abiotic carbonaceous inputs to Earth's oldest preserved sediments.

Raman spectroscopy has been put forward as an analytical technique with which to investigate these contentious microstructures. The application of Raman spectroscopy, however, has been just as controversial with respect to the identification of carbon type/structure and subsequent interpretation. Therefore, the goal of this review is to address the problems encountered by applying Raman spectroscopy to these enigmatic samples. In light of the controversy pertaining to the use of Raman spectroscopy to delineate the biogenicity of Archean putative microstructures, we provide a summary on what is currently accepted as Raman spectral signatures of biomolecules. We then follow the organic maturation pathway by Raman spectroscopy on bona fide microfossils of biological origin to various carbonaceous materials. A historical overview of Raman spectroscopy applied to Archean carbonaceous materials, an account of biogenicity interpretations, and the future way forward for Raman spectroscopy for these materials will be discussed.

\section{Raman Spectroscopy}

Although Raman spectroscopy is currently a popular technique for studying Archean carbonaceous materials, there are misconceptions about the information available from Raman spectroscopy and the interpretation of Raman spectra. Therefore, this section provides a brief overview of Raman spectroscopy, Raman spectroscopy of carbonaceous materials, Raman signatures of accepted biomolecules, and considerations for the interpretation of Raman spectra of carbonaceous material from Archean Earth sediments and potentially from Mars.

\subsection{Raman phenomenology}

Raman spectroscopy is a form of vibrational spectroscopy that has long been routinely used to identify and quantify chemical compounds. A Raman spectrum is a spectrum of the light scattered from a sample, which is irradiated with monochromatic radiation in the UV/visible or near-IR region. The light may be scattered either elastically (Rayleigh scattering) or inelastically (Raman scattering). In the case of
Raman scattering, the emergent light is shifted from its original frequency by a quantum of energy that corresponds to a molecular transition of the sample. The transition may be translational, rotational, vibrational, or electronic in nature. For a vibrational mode to be Raman active, a change in polarizability as the molecule vibrates is needed. Molecules consist of a nuclear structure surrounded by a complex field or cloud of electrons. Application of a potential field causes the electrons to ebb and flow so that they are slightly concentrated toward the + and away from the - of the applied field. The ease with which electrons respond to a given field is described as the polarizability. If the polarizability changes as the molecule vibrates, we observe Raman active modes shown as Raman bands in the spectrum. Raman bands are the frequencies that correspond to the energy levels of different functional group vibrations.

When the energy of the incident light coincides with the energy of an electronic transition of a molecule, new possibilities arise for Raman spectroscopy for these compounds of interest, via the resonance Raman effect. Judicious selection of tuning the excitation wavelength to the electronic absorption spectrum can produce selective significant enhancement of certain Raman bands. These Raman bands correspond to vibrational modes that involve motions of the atoms in the chromophore, that portion of the molecule where the electronic transition is localized. Because of its selectivity, since the resonance phenomenon permits the specific enhancement of the vibrational spectrum of one particular molecular species within a complex solution or mixture, other species in the mixture not resonantly enhanced show Raman spectra of much lower intensity (often by a factor of $10^{-5}$ ). Therefore, the information content of the spectra is high, by comparison with that available from Stokes (conventional) Raman scattering and IR spectroscopy. Resonance Raman spectroscopy is useful for investigating molecules such as RNA, DNA, amino acids, proteins (e.g., Storrie-Lombardi et al., 2001; Tarcea et al., 2007), carotenoids (e.g., Marshall et al., 2007b), and chlorophyll, all of which undergo electronic transitions when excited by UV or visible electromagnetic radiation.

\subsection{Raman spectroscopy of carbonaceous materials}

Although the short summary that follows is by no means exhaustive, it is intended to highlight some relevant steps in our understanding of the vibration spectrum acquired from carbonaceous materials, which is to be dealt with in the subsequent discussion. Carbon has several allotropes that can be synthesized by biological and nonbiological processes, and it can exist in a wide range of disordered forms. Raman spectroscopy has historically played an important role in the structural characterization of graphitic/ carbonaceous materials (e.g., Dresselhaus and Dresselhaus, 1982 and references therein) and has been widely used in the last four decades to characterize graphitic systems, such as pyrolytic graphite, carbon fibers, glassy carbon, nanographite ribbons, fullerenes, and carbon nanotubes. Raman spectroscopy has been found to be very sensitive to structural changes that perturb translational symmetry in carbonaceous materials, which thus makes this a powerful method by which to characterize carbon structure (e.g., Dresselhaus and Dresselhaus, 1982 and references therein). 
The reference structure for the Raman analysis of $s p^{2}$ carbons is the graphitic lattice. Graphite consists of stacks of parallel two-dimensional graphene sheets with carbon atoms that are arranged in hexagonal rings through localized inplane $2 s, 2 p_{x}$ and $2 p_{y}\left(s p^{2}\right)$ orbitals. The individual sheets are weakly bonded by delocalized out-of-plane $2 p_{z}$ orbitals, which overlap to give a delocalized electron system. The anisotropic graphite structure suggests different properties along different crystallographic axes, namely, very high inplane strength but very weak out-of-plane strength. In disordered carbonaceous materials, a large proportion of the carbon atoms are situated within defects (vacancies, dislocations, grain boundaries, and stacking faults) and strained lattice regions.

The Raman spectrum of carbonaceous materials can be divided into first- and second-order regions, depending on the degree of crystallinity. The first-order Raman spectrum is especially sensitive to the extent of the two-dimensional ordering, while the second-order Raman spectrum is most sensitive to the graphitization process, which yields the three-dimensional order of hexagonal graphite (Lespade et al., 1982). The graphitic lattice has dihedral (hexagonal) symmetry that belongs to the prismatic $\mathrm{D}_{6 \mathrm{~h}}^{4}$ point group. Vibrational analysis indicates this symmetry to have vibrational modes of the types $2 \mathrm{E}_{2 \mathrm{~g}}, 2 \mathrm{~B}_{2 \mathrm{~g}}, \mathrm{E}_{1 \mathrm{u}}$, and $\mathrm{A}_{2 \mathrm{u}}$ (Tuinstra and Koenig, 1970).

$$
\begin{aligned}
\Gamma_{\mathrm{vib}}= & \left.2 \mathrm{~B}_{2 \mathrm{~g}}+2 \mathrm{E}_{2 \mathrm{~g}}(\text { Raman active })+\mathrm{E}_{1 \mathrm{u}} \text { (IR active }\right) \\
& \left.+\mathrm{A}_{2 \mathrm{u}} \text { (IR active }\right)
\end{aligned}
$$

Only the two $\mathrm{E}_{2 \mathrm{~g}}$ modes are Raman active and have been identified with a Raman band at $1582 \mathrm{~cm}^{-1}$ and a lowfrequency scattering feature at $47 \mathrm{~cm}^{-1}$, while the $\mathrm{E}_{1 \mathrm{u}}$ and $\mathrm{A}_{2 \mathrm{u}}$ are IR active and can be observed in an IR spectrum at 1588 and $868 \mathrm{~cm}^{-1}$, respectively. The $B_{2 g}$ modes are optically inactive. The E-symmetry modes exhibit in-plane atomic displacements, while the A-symmetry modes have out-ofplane displacements. The spectral region between 1000 and $1800 \mathrm{~cm}^{-1}$, the carbon first-order spectrum, contains most of

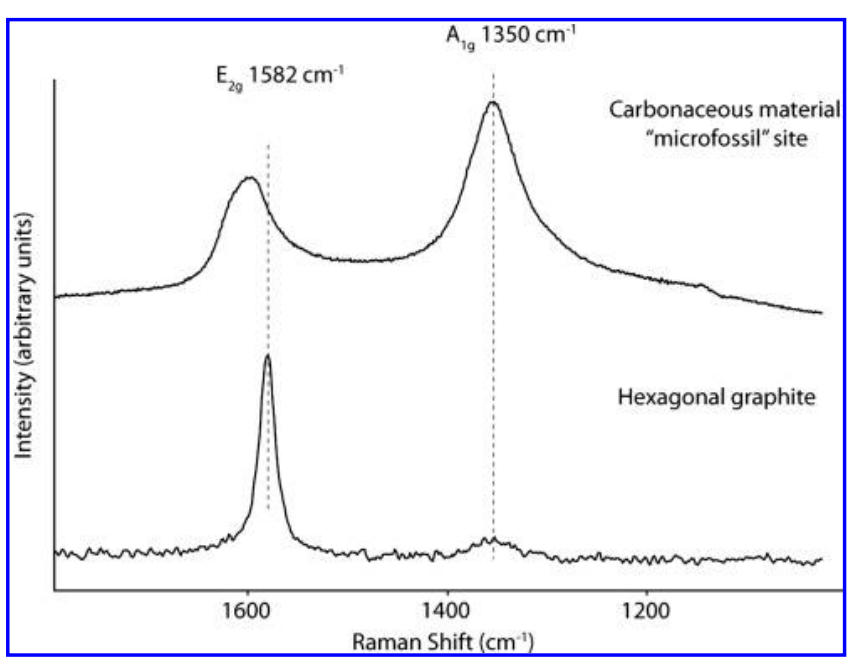

FIG. 1. Comparison stack plot of Raman first-order carbon spectra obtained from isolated kerogen from the Apex Chert dyke "microfossil site" and pure hexagonal graphite. the structural information of carbonaceous materials. Figure 1 shows a first-order spectrum of synthetic hexagonal graphite (Fluka, 99\% pure, 0.1\% ash, $<100 \mathrm{~mm}$ ) with a single band at $1582 \mathrm{~cm}^{-1}$ assigned to the $\mathrm{G}$ band, an in-plane $\mathrm{C}=\mathrm{C}$ in an aromatic ring stretching vibrational mode with $\mathrm{E}_{2 \mathrm{~g} 2}$ symmetry. However, when disordered $s p^{2}$ carbons are considered, significant spectral modifications can be observed that are related to increased bands due to structural disorder by lowering molecular symmetry. For example, Fig. 1 shows a first-order spectrum acquired from isolated [via a standard $\mathrm{HCl} / \mathrm{HF}$ acid digestion method as described in Marshall et al. (2007a)] carbonaceous material from the Apex Chert "microfossil" locality. Clearly, this spectrum is different from graphite as it is dominated by two broad bands. The additional band present at $1355 \mathrm{~cm}^{-1}$ is assigned to the $\mathrm{D}$ band with $\mathrm{A}_{1 \mathrm{~g}}$ symmetry, which becomes Raman active due to disorder in the $s p^{2}$ carbon network. This band has been attributed to a decrease in symmetry near the boundaries of microcrystalline domain, which reduces the symmetry from $D_{6 h}$ to $C_{3 v}$ or even $C_{s}$ (Tuinstra and Koenig, 1970; Mernagh et al., 1984). New vibrational modes of the lattice may then become active, such as an $\mathrm{A}_{1 \mathrm{~g}}$ mode (Tuinstra and Koenig, 1970). Alternatively, the D mode has been explained by the existence of specific vibrations at the edges, for example, oxides or $\mathrm{C}=\mathrm{C}$ groups that are present at the edge or other heteroatoms (S, N, O, and H) (Mernagh et al., 1984). Nonetheless, these studies concur that the $\mathrm{D}$ mode is related to structural disorder. Upon increasing disorder, the $G$ band becomes broader and shifts from 1582 to $1595 \mathrm{~cm}^{-1}$. In disordered $s p^{2}$ carbonaceous samples, the $\mathrm{G}$ band denotes that the sample contains $s p^{2}$ carbon networks that are not necessarily graphite. Clearly, therefore, the first-order spectrum acquired from the isolated carbonaceous material from the "microfossil" locality is composed of a network of disordered $s p^{2}$ carbon-not "graphitic kerogen" or "amorphous graphite" as previously reported by Schopf et al. (2002) and Brasier et al. (2002), respectively.

The $\mathrm{G}$ and $\mathrm{D}$ bands can be deconvolved into component bands, normally indicated as $\mathrm{Di}$, each arising from a vibrational mode of a disordered $s p^{2}$ lattice that becomes Raman active in the presence of structural disorder. A Gaussian/ Lorentzian fit is often used for crystals, arising from finite lifetime broadening, and it is normally used for disordered polycrystalline carbons and amorphous carbon (Ferrari and Robertson, 2000). Figure 2 shows a deconvoluted carbon first-order spectrum produced from the spectrum shown in Fig. 1, which was acquired from isolated carbonaceous material from the Apex Chert "microfossil" locality. It can be observed that five bands can be resolved into GaussianLorentzian bands, D2 (disordered $s p^{2}$ lattice) $c a .1615 \mathrm{~cm}^{-1}, \mathrm{G}$ (in-plane $\mathrm{C}=\mathrm{C}$ in an aromatic ring stretching vibrational mode with $\mathrm{E}_{2 \mathrm{~g} 2}$ symmetry) $c a .1598 \mathrm{~cm}^{-1}$, D3 (amorphous carbon) ca. $1545 \mathrm{~cm}^{-1}, \mathrm{D} 1\left(\mathrm{~A}_{1 \mathrm{~g}}\right.$ symmetry which becomes Raman active due to disorder in the $s p^{2}$ carbon network) $c a$. $1345 \mathrm{~cm}^{-1}$, and D4 $\left(s p^{3}\right.$ bonds or $\mathrm{C}-\mathrm{C}$ and $\mathrm{C}=\mathrm{C}$ stretching vibrations of polyene-like structures) $c a .1215 \mathrm{~cm}^{-1}$.

The second-order spectrum of isolated carbonaceous materials shows several bands ca. 2450, 2695, 2735, 2950, and $3248 \mathrm{~cm}^{-1}$ (Fig. 3). These second-order Raman bands are assigned to both overtone scattering $\left(2 \times 1360=2735 \mathrm{~cm}^{-1}\right.$, the most intense; $2 \times 1620=3240 \mathrm{~cm}^{-1}$, a weak but sharp band) and combination scattering $\left(1620+830=2450 \mathrm{~cm}^{-1}\right.$, 


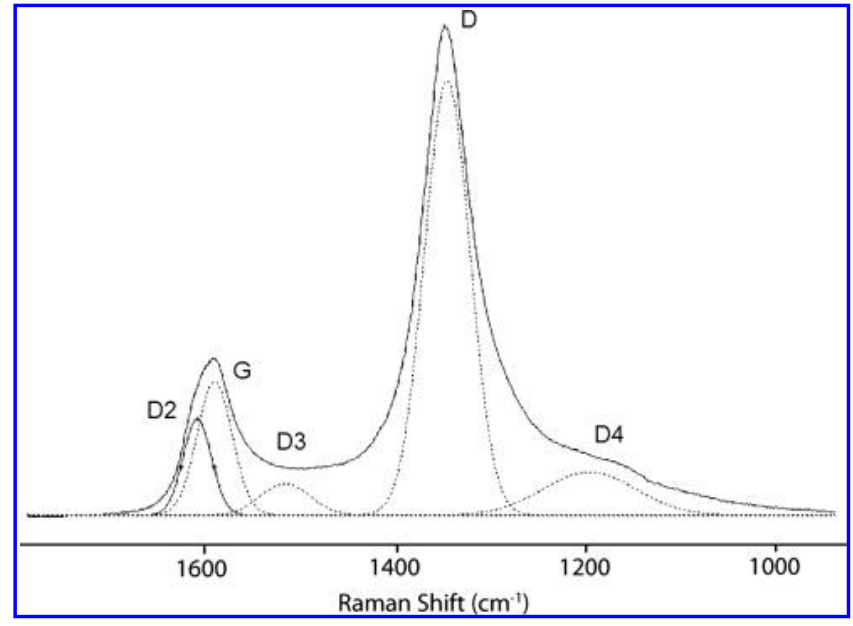

FIG. 2. Example of decomposition of the carbon first-order region of a Raman spectrum obtained from isolated kerogen from the Apex Chert "microfossil site." Five bands can be resolved into Gaussian-Lorentzian bands, D2 (disordered $s p^{2}$ lattice), $\mathrm{G}$ (in-plane $\mathrm{C}=\mathrm{C}$ in an aromatic ring stretching vibrational mode with $\mathrm{E}_{2 \mathrm{~g} 2}$ symmetry), D3 (amorphous carbon), $\mathrm{D} 1$ ( $\mathrm{A}_{1 \mathrm{~g}}$ symmetry becomes Raman active due to disorder in the $s p^{2}$ carbon network), and D4 ( $s p^{3}$ bonds or C-C and $\mathrm{C}=\mathrm{C}$ stretching vibrations of polyene-like structures).

$\left.1580+1355=2935 \mathrm{~cm}^{-1}\right)$. Lespade et al. (1982) attributed the appearance of these second-order bands to threedimensional structural ordering. In particular, the splitting of the band at $2700 \mathrm{~cm}^{-1}$ (S band) into the doublet of the $G_{1}^{\prime}$ and $G_{2}^{\prime}$ at 2695 and $2735 \mathrm{~cm}^{-1}$ occurs for well-crystallized graphite, which arises when carbonaceous materials acquire a triperiodic structure. Raman spectra can clearly be used to characterize the transition of carbonaceous materials between disordered and ordered structures. But using these changes in the Raman signature to determine either the biogenicity of the original structure or the causative factor in the diagenetic change and the degradation of the signal is a more complicated problem.

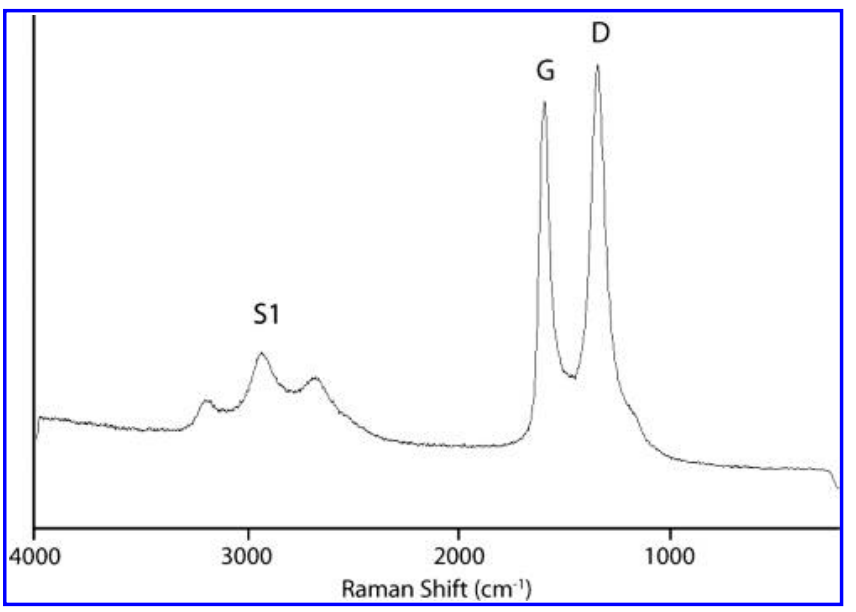

FIG. 3. An example of a first- and second-order Raman spectrum produced by carbonaceous materials. The spectrum was acquired on carbonaceous material isolated from the Strelley Pool Chert, Pilbara region, Western Australia.

\subsection{Accepted biogenic Raman spectral signatures}

Due to the current controversy of using Raman spectroscopy as a tool to asses the biogenicity of Archean putative microfossils, we will explore what are known and agreedupon spectral signatures for the evidence of life. The search for organic compounds of possible biological origin is one of the major goals of astrobiological exploration programs of NASA and ESA. Both NASA and ESA are considering the importance of miniaturized Raman spectrometers for future robotic exploration missions to Mars as part of the analytical instrumentation suite on planetary landers. Therefore, a compilation of a Raman spectral database for biological materials is needed to confirm the presence of extinct or extant life on Mars. Examples of potential biomolecular materials with this goal in mind are molecular structures that define their functionality, such functionality being fundamental to all organisms. Furthermore, it is desirable to target molecules that are clearly distinguished from abiogenic compounds that are widely distributed throughout the Cosmos. Potential molecules that could serve as biosignature compounds to target include DNA/RNA and proteins, chlorophyll (degrades to porphyrins), carotenoids/retinalprotein complexes (degrade to isoprenoids), cell membranes containing bacteriohopanetretol (degrade into hopanoids), and steroids (derived from the degradation of eukaryote cell membranes and walls) (Marshall et al., 2006).

Vibrational spectroscopy of biological samples provides information about the chemical composition of all cell components. Pioneering work by Naumann et al. (1991a, 1991b) showed that IR and Raman spectroscopy can be used to classify bacteria and yeasts. Using deep UV excitation (e.g., $244 \mathrm{~nm})$, direct investigation of macromolecules such as DNA or proteins becomes possible due to resonant enhancement (e.g., Manoharan et al., 1990; Chadha et al., 1993; Wu et al., 2001; Jarvis and Goodacre, 2004). Storrie-Lombardi et al. (2001) and Tarcea et al. (2007) showed that Raman excitation wavelengths in the deep UV region are able to selectively enhance Raman signals of proteins and DNA/RNA. The signals can mainly be assigned to DNA bases as well as aromatic amino acids. Additionally, because the Raman signals of the DNA bases guanine, adenine, cytosine, and thymine as well as the RNA base uracil are resonantly enhanced, it is possible to correlate the UV-resonance Raman spectra with the GC value. The GC value is defined as the ratio of guanine and cytosine to all DNA bases. Significantly, from an astrobiological perspective, this can be used as a criterion for the presence of life; and potentially it could be used as taxonomic criterion, since the GC value is species specific. Conceivably, this could offer information on the relatedness between Earth and potential martian microbes.

Investigations of endolithic communities from extreme habitats on Earth have demonstrated that Raman spectroscopy is an excellent tool to detect various types of biomolecules that have been produced by particular microorganisms as part of their survival strategy in extreme environments (see Wynn-Williams and Edwards, 2000a, 2000b; Edwards et al., 2004, 2005a, 2005b; Villar et al., 2005; Villar and Edwards, 2006). Photoprotective pigments provide an important group of biomolecules that are produced as a response to harmful UV radiation and act as UV-screening compounds (e.g., parietin and scytonemin) or indirectly as 
antioxidants (carotenoids) that quench the reactive oxygen species responsible for cellular damage; for a detailed review, see Edwards et al. (2005a). Due to recent identification of evaporites on Mars by the NASA rovers Spirit and Opportunity, it is reasonable to assume that halophilic microorganisms could have flourished in the martian environment. Based on these results, it is conceivable that brine pools may have been relatively common on the surface of that planet. Brines or evaporites may be suitable habitats for extant halophilic microorganisms or the last refuge for an extinct life (Mancinelli et al., 2004) and thus potentially bear a fossil record. Recently, Marshall et al. (2007b) reported on the identification of carotenoids in halophilic archaea by resonance Raman spectroscopy, using a laser with an excitation wavelength of $514.5 \mathrm{~nm}$. This excitation wavelength has proven to be useful when analyzing carotenoids due to its coincidence with an electronic transition in carotenoids, which results in the Raman resonance effect and thus significantly enhances the Raman signal.

Shown in Fig. 4 is a stack plot comparison of Raman spectra produced by an extant endolithic community dominated by cyanobacterium (Nostoc sp.), synthetic $\beta$-carotene (purchased from Sigma Aldrich), synthetic $\beta$-carotane [purchased from Chiron and prepared as in Marshall and Marshall (2010)], a thermally immature acid-extracted [standard $\mathrm{HF} / \mathrm{HCl}$ preparation as described in Marshall et al. (2005)]

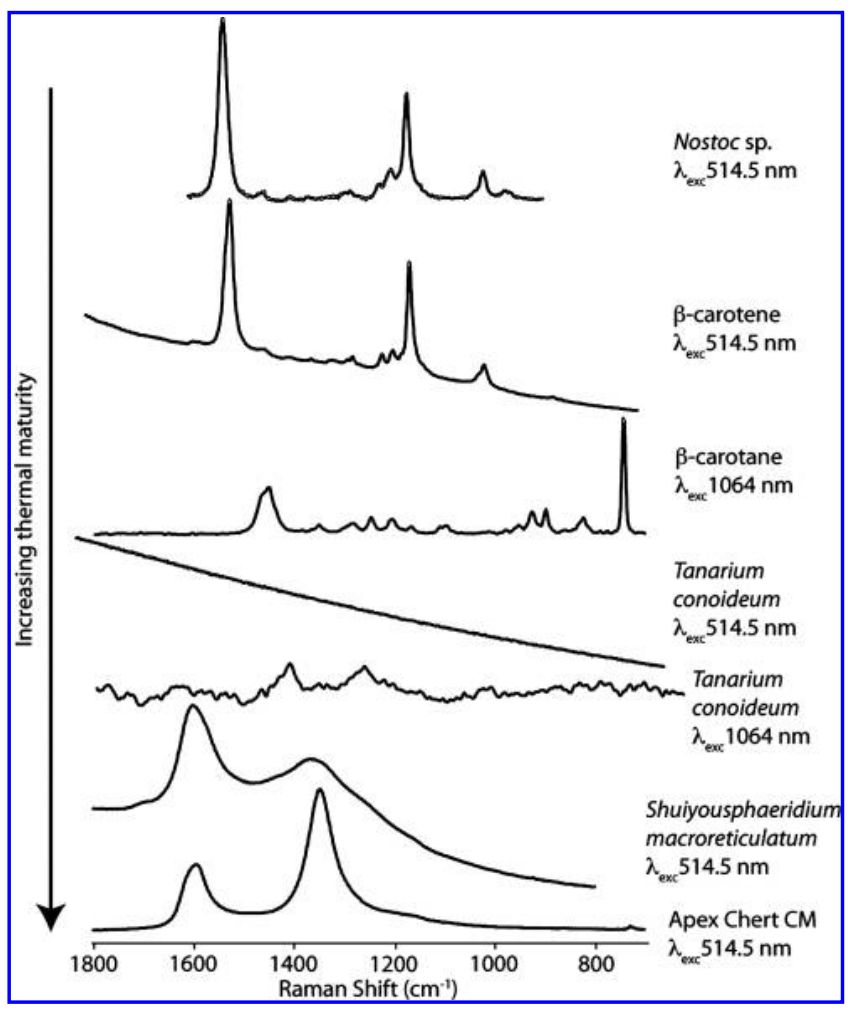

FIG. 4. Stack plot comparison of Raman spectra from an analysis of an extant natural endolithic community (dominated by the cyanobacterium Nostoc sp.), $\beta$-carotene, $\beta$-carotane, a thermally immature acritarch Tanarium conoideum (ca. 590-565 Ma), a thermally mature acritarch Shuiyousphaeridium macroreticulatum (ca. 1.4-1.3Ga), and thermally over-mature carbonaceous material (CM) from the Apex Chert (ca. 3.5 Ga). acritarch Tanarium conoideum (ca. 590-565 Ma, from Observatory Hill \#1 drill core, Tanana Formation, Australia), a thermally mature acid-extracted acritarch Shuiyousphaeridium macroreticulatum [ca. 1.4-1.3 Ga from an outcrop section in the Ruyang Group, China (Marshall et al., 2005)], and thermally over-mature (i.e., heated beyond the oil window) carbonaceous material collected by one of us (C.M.) in 2006 from a "microfossil site" of the Apex Chert (ca. 3.5 Ga). As an overall trend, the Raman spectra of these extant microbes, pigments, and degraded materials can range from complicated organic spectra assignable to biomolecules and mainly a photoluminescence background, to two distinct bands that can be assigned to disordered $s p^{2}$ carbonaceous material. The Raman spectra acquired from the endolithic community and $\beta$-carotene have three dominant bands $c a .1000,1152$, and $1520 \mathrm{~cm}^{-1}$, which are due to in-phase $\mathrm{C}=\mathrm{C}\left(v_{1}\right)$ and $\mathrm{C}-\mathrm{C}$ stretching $\left(v_{2}\right)$ vibrations of the polyene chain in carotenoids and in-plane rocking modes of $\mathrm{CH}_{3}$ groups attached to the polyene chain coupled with $\mathrm{C}-\mathrm{C}$ bonds, respectively (Marshall et al., 2007b). By comparison, the diagenetically transformed carotenoid $\beta$-carotane has additional bands than that of the $\beta$-carotene spectrum. The band at $1455 \mathrm{~cm}^{-1}$ is assigned to $\delta\left(\mathrm{CH}_{2}\right)$ scissoring mode of methylene, numerous bands between $1390-1000 \mathrm{~cm}^{-1}$ are assigned to $v(\mathrm{C}-\mathrm{C})$ stretching, and bands between $1000-800 \mathrm{~cm}^{-1}$ are assigned to a combination of $\delta(\mathrm{C}=\mathrm{CH})$ methyl in-plane rocking and $\delta(\mathrm{C}-\mathrm{H})$ out-of-plane bending modes (Marshall and Marshall, 2010). From an astrobiological perspective, it is desirable to target organic molecules that are clearly distinguished from abiogenic compounds. Clearly, the Raman spectroscopy of functionalized carotenoids, RNA, and DNA unequivocally fulfils this objective, as they are only synthesized by biological processes and display unique diagnostic spectra for this compound class. We propose here that likewise diagenetically reduced carotenoids can only be formed by fossilization processes and moreover provide unique diagnostic spectra.

\subsection{Loss of definitive biogenic Raman spectral signatures as a consequence of thermal stress}

We will further discuss spectral interpretation below, but consider now the thermal evolution of organic matter as a response to increasing burial and time. Sedimentary organic matter is composed mainly of carbon, hydrogen, and oxygen, and in some cases sulfur and nitrogen. Upon increasing thermal maturity, oxygenated functional groups and their sulfur and nitrogen equivalents are released first and form, for example, $\mathrm{CO}_{2}, \mathrm{H}_{2} \mathrm{O}$, and $\mathrm{SH}_{2}$. Aliphatic $\mathrm{CH}$ groups are then removed, which form aromatic units. As a consequence, the amount of biological information preserved is reduced and subsequently lost as progressive thermal stress leads to the formation of aromatic hydrocarbons (Fig. 5). This transformation, which is called carbonization, proceeds through a series of intermediate forms that may ultimately convert to a triperiodic graphite structure, that is, the process of graphitization. The transformation from short and disorientated aromatic layers in poorly organized carbonaceous material up to perfectly stacked layers in the triperiodic structure of graphite is achieved by microtextural, structural, and chemical modifications of the starting material with increasing thermal stress. As the aromatic layers become larger and 


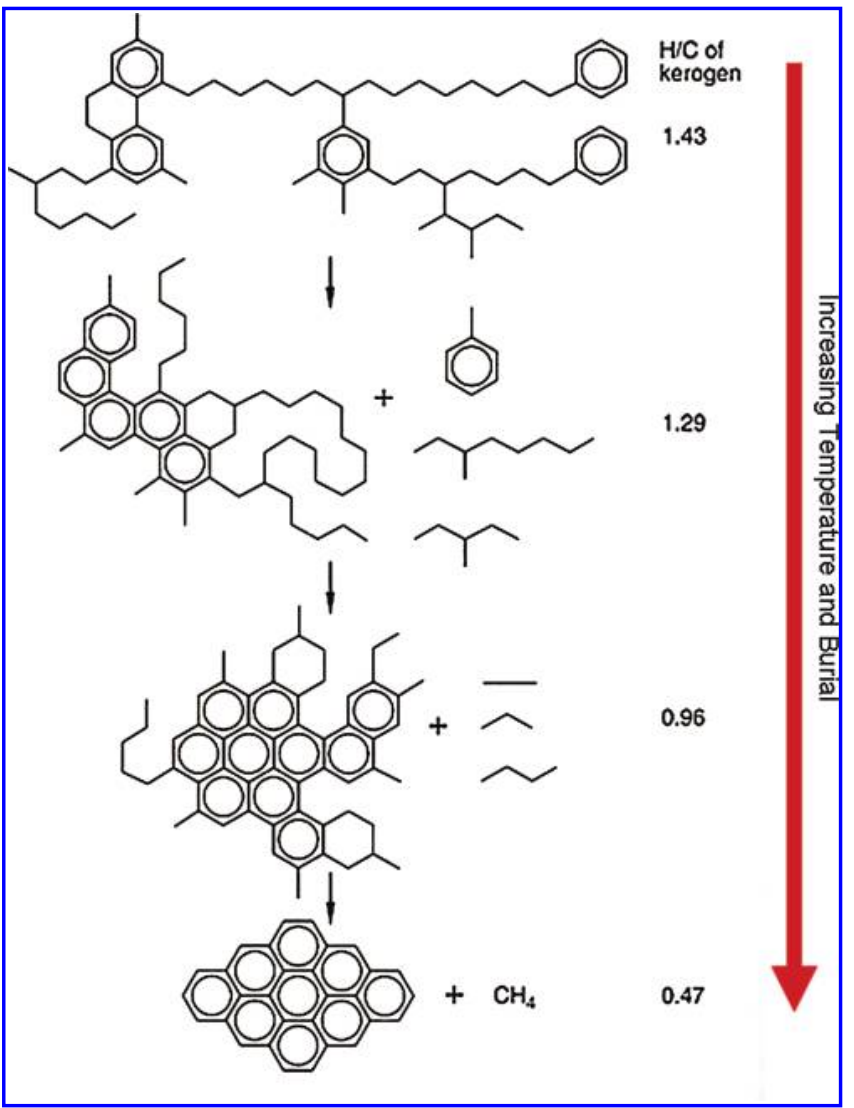

FIG. 5. A molecular cartoon that illustrates the thermal maturation of organic matter with increasing temperature as a response to subsequent burial and time. Color images available online at www.liebertonline.com/ast.

when their stacking becomes ordered, both compositional and organizational changes are involved while the organic material is undergoing graphitization. The ultimate degree of graphitization strongly depends on both composition and organization of the starting material (Bény-Bassez and Rouzaud, 1985; Rouzaud and Oberlin 1989; Kř́ibek et al., 1994).

Figure 4 shows two spectra obtained from Tanarium conoideum collected at 514.5 and $1064 \mathrm{~nm}$ (details in Marshall et al., 2006). The spectrum obtained at $514.5 \mathrm{~nm}$ exhibits a pronounced photoluminescence background with no discernable bands. The Raman spectroscopic analysis of aliphatic macromolecules (such as immature kerogens, biopolymers, and microfossils) with an excitation at 514.5 or $532 \mathrm{~nm}$ is commonly obscured by the intense fluorescence, due to saturated carbon-hydrogen structures $(\mathrm{C}-\mathrm{H})$. The Raman effect has a very small quantum; therefore, when exciting radiation of the visible range is applied, the weak Raman lines are overlaid by the fluorescence radiation from the aliphatic macromolecule. Fluorescence is the emission of light with a longer wavelength than the incident light and is an electronic effect with a longer lifetime than the Raman effect. Its intensity maximum is located between 300 and $700 \mathrm{~nm}$ and conceals a large part of the actual Raman spectrum. This obstacle, however, can be circumvented by reducing the energy of the exciting light quanta to the degree at which the electronic states are not excited. On excitation at
$1064 \mathrm{~nm}$ of a Nd:YAG laser, the fluorescence is eliminated, and two bands can be observed at $1450 \mathrm{~cm}^{-1}$ assigned to $\delta\left(\mathrm{CH}_{2}\right)_{\mathrm{sc}}$ scissors, and at $1295 \mathrm{~cm}^{-1}$ assigned to $\delta\left(\mathrm{CH}_{2}\right)_{\mathrm{tw}}$ twisting (Marshall et al., 2006).

The Raman spectrum acquired from a thermally mature acritarch Shuiyousphaeridium macrorecticulatum (Fig. 4) shows two broad asymmetrical bands at ca. 1600 and $1360 \mathrm{~cm}^{-1}$ assigned to disordered $s p^{2}$ carbon. The final spectrum in Fig. 4 was acquired from carbonaceous material from the Apex Chert, which also shows two broad asymmetrical bands at $c a$. 1600 and $1360 \mathrm{~cm}^{-1}$ assigned to disordered $s p^{2}$ carbon, although they are different in line shape and intensity for the spectrum acquired from Shuiyousphaeridium macrorecticulatum. Upon increasing thermal stress, biological functionality of organic matter is lost, and the subsequent product of thermal stress is the generation of covalently cross-linked aromatic hydrocarbons and other aromatic subunits that get transformed and condensed through carbonization and graphitization. Currently, there is no agreement as to how to determine by Raman spectroscopy a biogenic signal for such thermally altered material. To date, this has been the problem in how to assess the biological/ abiological nature of these materials.

\subsection{Considerations for the Raman spectra of potential martian carbonaceous materials}

Currently, there is debate as to what would be the best choice of the wavelength of laser line used for sample excitation for Raman spectroscopy in astrobiological prospecting. Possible wavelengths of laser lines that have been proposed are $244 \mathrm{~nm}$ (e.g., useful for DNA and proteins), 514.5 and $532 \mathrm{~nm}$ (e.g., useful for resonance enhancement of carotenoids and minerals), and $785 \mathrm{~nm}$ (e.g., useful for organics and minerals). Thus far, the Mars Microbeam Raman Spectrometer developed at NASA's Jet Propulsion Laboratory will use a low-power-mode $532 \mathrm{~nm}$ laser for sample excitation (Wang et al., 2003). However, the excitation wavelength for the ESA Raman system (Raman Laser Spectroscopy) is still under debate (Courreges-Lacoste et al., 2007). Of particular concern to astrobiological applications, with respect to the analysis and interpretation of carbonaceous materials, is that the frequency and intensity of the D band is dependant upon laser excitation wavelength (e.g., Vidano et al., 1981; Pocsik et al., 1998). Over the following range of laser excitation, $244-1064 \mathrm{~nm}$, the $\mathrm{G}$ band position and intensity are practically independent of excitation wavelength, whereas the $\mathrm{D}$ band shows an apparent linear variation of its position (amounting to about $180 \mathrm{~cm}^{-1}$ in the measured range), and intensity (Pocsik et al., 1998) strongly depends on the excitation wavelength. This phenomenon is attributed to a resonance enhancement effect of the $\mathrm{D}$ band (Pocsik et al., 1998). The standard wavelength of choice for the analysis of carbonaceous materials is either 514.5 or $532 \mathrm{~nm}$. Therefore, consideration needs to be given with respect to the resonance effects of the $\mathrm{D}$ band when comparing acquired spectra to that of previous carbonaceous material standard spectra obtained at either 514.5 or $532 \mathrm{~nm}$.

It is relevant here to discuss the impact of chemically reactive ions, martian radiation loads, and superoxide radicals that form secondary to heavy particle bombardment of carbonaceous materials within the martian regolith. These 
energetic ions and particles break chemical bonds and displace atoms, change the molecular structure (inducing disorder-amorphization) and microtexture, and can form new molecular species. Raman spectroscopy has been used to study the effects of ion-induced lattice damage in carbonaceous solids and organic compounds (e.g., Elman et al., 1981; Strazzulla et al., 2001 and references therein). It has been demonstrated that, when carbonaceous materials are ion irradiated, there is either an increase or decrease in the $s p^{2}$ carbonaceous cluster size, dependant upon starting material. During ion irradiation, two competitive processes are present: graphitization and amorphization. The first process is related to the energy release in the form of heat ("thermal spikes") inside the collision cascade (i.e., $s p^{3}$ to $s p^{2}$ conversion with or without hydrogen loss), while the second process is caused by displacement collisions and depends on the size of crystallites. Therefore, these energetic processes greatly affect the carbon first-order spectrum, that is, the G and D band position, width, and relative intensity. These parameters are directly linked to the lattice structure, which changes after ion irradiation. Clearly, these processes must be borne in mind when interpreting the carbon first-order spectrum of possible martian carbonaceous materials in terms of elucidating the nature and origin of these materials.

\section{Practical Considerations in Raman Spectroscopy of Carbonaceous Materials}

There are two issues to be considered with the application of Raman spectroscopy to carbonaceous materials: the stability of the sample and, for highly anisotropic graphitic materials, the orientation of the sample relative to the laser beam.

\subsection{Stability under laser irradiation}

An important problem associated with black, absorbing carbonaceous samples is their heating and possible transformation under laser radiation during Raman spectroscopic analysis. This problem is especially important for samples with a low degree of structural order, that is, low-carbonified and non-graphitized samples. To circumnavigate the heating problem, granular samples can be pressed onto gold foil, which acts as a heat sink during measurements (Wopenka and Pasteris, 1993). Additionally, defocusing of the laser beam can be sufficient, depending on the sample material. In most cases, however, and especially for unstable carbonaceous samples, low laser powers are recommended. After measurements in individual areas, the optical microscope makes it possible to observe whether the laser-illuminated area has sustained damage during analysis. This is important for Archean studies on Earth in which laboratory Raman spectrometers are used. With respect to minaturized Raman systems to be used for Mars exploration, for example, the Mars Microbeam Raman Spectrometer system will use a $532 \mathrm{~nm}$ laser that can operate in a low-power mode for the detection of heat-sensitive materials, which is particularly useful for samples such as disordered $s p^{2}$ carbonaceous materials (Wang et al., 2003).

\subsection{Orientation}

The Raman spectrum and the ratio of both $G$ and $D$ bands depend not only on the degree of graphitization but also on the scattering geometry during analysis. Differences are observed for graphitic planes oriented parallel or perpendicular to the polarization orientation of the exciting laser beam (Nakamizo et al., 1974; Vidano et al., 1981; Wang et al., 1989). The effects of orientation on the Raman spectra require caution in the interpretation of spectra from carbonaceous samples. This can be especially restrictive for highly anisotropic crystalline graphitic carbons from polished sections. It is recommended that multiple laser alignments are used to gather Raman spectra from a sample. For example, the laser can be orientated at $90^{\circ}$ and $180^{\circ}$ to the sample, which enables the acquisition of data that can be used to determine the effect of orientation. These data can help distinguish periodic, chaotic, and the true random heterogeneity in the carbonaceous material's crystalline structure for that sample.

\section{History of Raman Spectroscopy Applied to Archean Carbonaceous Materials}

Surprisingly, the first application of Raman spectroscopy of Archean carbonaceous microstructures was a little-cited and forgotten study undertaken by Pflug and Jaeschke-Boyer (1979). They reported chemical and morphological evidence of the presence of microfossils of an apparently eukaryotic character in the $3.8 \mathrm{Ga}$ chert layers of a quartzite of the Isua series in Southwest Greenland. Raman spectroscopy showed "hydrocarbons of high aromatization and condensation similar to those present in asphaltites." In addition, some of their samples contained "amorphous carbon produced by charring of organic material." Pflug and Jaeschke-Boyer (1979) suggested that the organic material that constitutes the microstructures was in a "carbonized condition, partly in a high rank of coalification very similar to a final stage of graphitization," which is "in accordance with the metamorphic condition of the enclosing rock of an upper greenschist facies." The Raman spectra of the material in the vacuoles of these cells, however, show the composition to be carbonyl groups, esters, and aliphatic hydrocarbon. The authors attributed this functionalized organic material to the preservation of the vacuoles due to special conditions in the cherts. Clearly, this low-molecular-weight functionalized organic material can be interpreted as younger organic contamination.

Soon, however, the nature of these carbonaceous spherical microstuctures was disputed by Bridgwater et al. (1981) and Roedder (1981). Bridgwater et al. (1981) put forward two main arguments. First, they asserted that the putative microfossils were indistinguishable from limonite-stained fluid inclusions-microstructures that are demonstrably inorganic and post-depositional in origin (Bridgwater et al., 1981). Notably and despite this first argument, the Raman spectra indicate disordered $s p^{2}$ carbon and a younger contaminated source of functionalized carbon. Secondly, and more interestingly, Bridgwater et al. (1981) proposed that the occurrence of hydrocarbons within these microstructures, if confirmed, would be equally consistent with both a biological and nonbiological origin of these compounds. Roedder (1981) showed by petrographic analysis that the microstructures were limonite-stained cavities from the complete dissolution by weathering of ferruginous dolomite, despite Raman spectroscopy demonstrating the presence of disordered $s p^{2}$ carbon. Appel et al. (2003) demonstrated, however, 
that the extreme stretching deformation the metachert underwent could not have preserved syndepositional (microstructures deposited at the same time of sedimentation) spherical carbonaceous objects. As a consequence, Appel et al. (2003) concluded that the carbonaceous objects, whether biological or not, were entirely post-tectonic and more likely a result from pre-Quaternary weathering.

A later, little-cited Raman spectroscopic study by Pflug (1984) of spherical microstructures from the ca. $3.4 \mathrm{Ga}$ old sedimentary rocks of the Swaziland System in eastern South Africa revealed these to be carbonaceous in composition. There was no question of doubt in this study: the carbonaceous material exhibited Raman spectra that would be expected for that degree of metamorphism; moreover, the microstructures were indigenous syndepositional features. However, after these initial studies by Pflug and JaeschkeBoyer (1979) and Pflug (1984), there was a hiatus in the application of Raman spectroscopy to Archean carbonaceous materials. Only recently, renewed interest in the Raman spectroscopy of Archean carbonaceous microstructures has occurred. Ueno et al. (2001a, 2001b) were the next to investigate filamentous microstructures in silica veins at a $3.5 \mathrm{Ga}$ North Pole chert-barite unit by carbon isotopic measurements, using secondary-ion mass spectrometry and Raman spectroscopy. Ueno et al. (2001a, 2001b) showed that the black filamentous microstructures and clots were composed of carbonaceous material as revealed by the Raman spectra having $\mathrm{G}$ and $\mathrm{D}$ bands diagnostic of carbonaceous materials. Ueno proposed that this was not an indicator of biogenicity but rather that the microstructures were composed of carbon. Moreover, they used the ratios of these bands to indicate a metamorphic grade of lower greenschist facies, which thus suggests that these carbonaceous filaments were syngenetic (carbonaceous filaments were deposited at the same time of sedimentation, meaning they are indigenous).

Schopf et al. (2002) undertook Raman point-by-point analysis and mapping (a technique well established in the carbonaceous materials literature) on filamentous microstructures in a single chert unit within the $3.5 \mathrm{Ga}$ Apex Basalt, and concluded that the microstructures were composed of "graphitic kerogen." Furthermore, they defined kerogen as preserved sedimentary biogenic carbon, which is in stark contrast to the organic geochemical operational definition of acid insoluble carbonaceous material (Durand, 1980). Consequently, this led to an erroneous supposition that Raman spectroscopy yields a diagnostic "kerogen signal," which thus infers the biogenicity of these microstructures. This generated enormous controversy and consequently led to a series of papers debating this issue.

Brasier et al. (2002) investigated the same material as the Schopf et al. (2002) study and interpreted their Raman spectra as "amorphous graphite." They thereby proposed that this material was abiotic graphite that was produced by a Fischer-Tropsch type synthesis. Given their extensive field mapping and geochemical work, they interpreted the depositional setting of this chert unit as that of a hydrothermal system. Therefore, they invoked the formation of these carbonaceous microstructures by Fischer-Tropsch type synthesis of carbon compounds in a hydrothermal setting. Fischer-Tropsch type synthesis, while well established in the industrial world (Anderson, 1984), is not well understood in the natural environment. In geochemistry, the term Fischer-
Tropsch synthesis is often incorrectly used. More correctly, it is an industrial process that reacts carbon monoxide with hydrogen in the presence of transition metal catalysts, for example, iron or zinc or their oxides, to produce lowmolecular-weight linear alcohols and hydrocarbons. There has been no detailed molecular mechanism proposed that explains how small amounts of simple apolar organics (predominantly low-molecular-weight $n$-alkanes and analogous $n$-alcohols) produced from Fischer-Tropsch synthesis can be transformed into significant quantities of highly aromatic kerogens; moreover, this has never been demonstrated experimentally.

The Schopf et al. (2002) study came under further critique by Pasteris and Wopenka (2002, 2003), who made a very salient point that the spectral signature obtained from kerogen (of known biological origin) is similar to spectra obtained from many poorly ordered carbonaceous materials that arise through abiotic processes. Yet there is still confusion in the literature as to whether the Raman spectroscopy of carbonaceous materials can indeed delineate a signature of ancient life.

Most recent studies use Raman spectroscopy to confirm the carbonaceous composition and syngenicity of microstructures by delineating the degree of carbon structural order (e.g., Tice et al., 2004; van Zuilen et al., 2005; Allwood et al., 2006; Westall et al., 2006; Marshall et al., 2007a; van Zuilen et al., 2007; Lepot et al., 2008). Interestingly, Edwards et al. (2007) observed Raman signals for disordered $s p^{2}$ carbonaceous materials, carotenoids, and porphyrins acquired from cherts from the Trendall and Kitty's Gap localities from the Panorama Formation, Pilbara, Western Australia. Raman signals for carotenoids and porphyrins were measured in, or near, fractures within the hand specimens of the chert samples (see Fig. 4 for Raman signals of carotenoids compared to disordered $s p^{2}$ carbonaceous materials). Therefore, the presence of these thermally labile compounds can be attributed to the contamination of the sample by the presence of endolithic and chasmolithic microbes. Endolithic microorganisms live in cracks or fractures in rocks, in spaces between grain boundaries within a rock (chasmoendolithic), and in pore spaces between grains (cryptoendolithic). They may also bore into shells, bones, and carbonate rocks or particles (euendolithic). Endolithic microorganisms include bacteria, fungi, algae, and lichens. Not only can microorganisms penetrate cracks and microfissures within rocks, but organic detritus and dissolved organic substances can be washed into cracks by rainwater. Similar contaminating features were observed in the martian meteorite Nakhla (Toporski and Steele, 2007). Therefore, extra caution must be applied in the subsequent interpretation of finding various thermally liable functionalized organic compounds in ancient metamorphosed Archean cherts and extraterrestrial materials for extraordinary claims of ancient or martian life.

\section{Raman Spectroscopy as a Geothermometer for Archean Carbonaceous Materials}

Currently, Raman spectroscopy can be used to demonstrate that Archean microstructures have a carbonaceous composition, but it cannot provide any insight on their biogenicity. However, the crystallinity of carbon can be used as a proxy for the diagenetic and metamorphic history. The 
following section gives an overview on using the Raman first-order carbon spectrum to delineate thermal maturity.

In 1985, French geochemists Bény-Bassez and Rouzaud published an important paper giving the results of structural investigation by Raman microspectroscopy of four reference carbon types during laboratory high-temperature treatments (HTT). Precursor artificial materials included anthracene, thin and thick carbon films, and saccharose. These carbonaceous compounds are representatives of so-called graphitizing and non-graphitizing carbons, as defined by Franklin (1951). Non-graphitizing means that the carbonaceous matter is not transformed into graphite during high-temperature laboratory treatment, under an inert gas atmosphere, of up to $2800^{\circ} \mathrm{C}$. Using Raman microspectroscopy, investigators were able to detect different types of defects and follow their elimination during HTT. The evolution of carbonaceous materials throughout artificial HTT (carbonization and graphitization) is due to the rapid and almost complete elimination of different types of defects. This elimination allows the progressive rearrangement of the basic structural units. In the case of graphitizing materials, Raman spectra enabled documentation of the occurrence of well-crystallized graphite after HTT up to $2700^{\circ} \mathrm{C}$. For non-graphitizing carbon, such as cellulose, disorder persisted, and the crystalline structure of graphite was not obtained even after HTT to $2900^{\circ} \mathrm{C}$ (Rouzaud and Oberlin, 1989). It was proposed that the in-plane graphite crystallite size $\left(\mathrm{L}_{\mathrm{a}}\right)$ of polycrystalline materials can be deduced by comparing the intensity of the $\mathrm{E}_{2 \mathrm{~g}}$ mode band at $1582 \mathrm{~cm}^{-1}\left(\mathrm{I}_{\mathrm{G}}\right)$ to the intensity of the disorder-induced band at $1350 \mathrm{~cm}^{-1}\left(\mathrm{I}_{\mathrm{D}}\right)$ (Knight and White, 1989):

$$
\mathrm{L}_{\mathrm{a}}=4.4 \mathrm{I}_{\mathrm{G}} / \mathrm{I}_{\mathrm{D}}(\text { in } \mathrm{nm})
$$

On the basis of previous studies carried out on different synthetic precursors and with the use of detailed sampling of carbonaceous matter for specimens of different metamorphic series, knowledge about the evolution of Raman spectra of carbonaceous matter has been progressively obtained. By combining Raman data with those obtained by other methods of structural investigation such as X-ray diffraction and transmission electron microscopy, changes during regional metamorphism at the atomic and molecular level of carbon from rocks of different age have been described (Pasteris and Wopenka 1991; Jehlička and Bény 1992, 1999; Wopenka and Pasteris, 1993; Kříbek et al., 1994; Jehlička et al., 1997; Beyssac et al., 2002a, 2002b, 2003). However, investigators have indicated that care must be taken when more than one population of primary carbonaceous matter is documented in the investigated samples (Kř́ibek et al., 1994; Rantitsch et al., 2004).

In their pioneering work, Pasteris and Wopenka (1991) showed that the Raman spectra of graphite in rocks reflect the degree of crystallinity $\left(\mathrm{L}_{\mathrm{a}}\right)$ in natural samples in a similar fashion as exhibited in the case of carbonaceous precursors heated in laboratory ovens (Bény-Bassez and Rouzaud, 1985). They demonstrated that the Raman spectrum is a sensitive fingerprint of changes in the degree of graphitization in rocks from greenschist-to-granulite facies metamorphism.

Important changes in the Raman spectra were observed for residual carbonaceous matter isolated from a homoge- neous series of Barrandian black shales and schists from the western part of the Bohemian Massif (Neoproterozoic). This evolution documented natural metamorphic graphitization in the direction of increasing regional metamorphism. In the series of kerogens investigated from rocks between pumpellyite and biotite zone, the intensity ratio of the bands $\mathrm{D}$ to $\mathrm{G}$ decrease in the direction of regional metamorphism from values around 1.4 to less than 0.1 (Jehlička and Bény, 1992), which correlates inversely with the dimension of crystallite size $\left(\mathrm{L}_{\mathrm{a}}\right)$ visualized when using transmission electron microscopy (Jehlička and Rouzaud, 1990). In poorly ordered kerogens from black shales subjected only to very low metamorphic conditions, two broad Raman bands (halfmaximum width $60-80 \mathrm{~cm}^{-1}$ ) were observed in the Raman spectra, the first situated at about $1590 \mathrm{~cm}^{-1}$, the second at $1350 \mathrm{~cm}^{-1}$. In the case of kerogens from schists of the chlorite metamorphic zone, both of the characteristic Raman bands were again observed; however, they were slightly narrower $\left(50-60 \mathrm{~cm}^{-1}\right)$ in comparison with those in spectra of poorly ordered kerogens from low metamorphic areas. The Raman spectrum of carbonaceous matter from the biotite metamorphic zone is characterized by a sharp and narrow $\left(32 \mathrm{~cm}^{-1}\right.$ band width) band at $1578 \mathrm{~cm}^{-1}$. A very weak band at $1354 \mathrm{~cm}^{-1}$ was observed, which confirmed that under these metamorphic conditions the carbonaceous matter was transformed to graphite (Jehlička and Bény, 1992).

Wopenka and Pasteris (1993) investigated an important series of carbons-among other samples, 24 grain separatesfrom various metamorphic terrains from chlorite zone to granulite facies. The Raman shift positions, widths, height ratios, and area ratios of the Raman bands evolve in correlation with the degree of ordering. On the other hand, they were able to estimate the in-plane crystallite size, $L_{a}$, based on the existing calibration data (X-ray diffraction).

Yui et al. (1996) showed that continuous sampling from zeolite facies through prehnite-pumpellyite facies to greenschist facies metamorphic rocks revealed that both the Raman D/G band area (i.e., integrated intensity) ratio and the $D / G$ band width (i.e., full width at half maximum) ratio of the carbonaceous material decrease with progressive metamorphism but that the most prominent change in the $\mathrm{D} / \mathrm{G}$ band area ratio occurs in samples of lower greenschist facies metamorphic grade, while the most significant decrease in the $D / G$ band width ratio occurs in samples near the boundary of prehnite-pumpellyite and greenschist facies. It was postulated that the Raman spectrum of carbonaceous material can serve as a metamorphic grade indicator to distinguish samples of a prehnite-pumpellyite facies metamorphic grade from those of a greenschist facies metamorphic grade.

Beyssac et al. (2002b) proposed that the structural organization of carbonaceous material can be quantified through the $\mathrm{R} 2$ parameter, which is defined as the relative area of the main defect band D1, with respect to the G and D2 bands, given by

$$
\mathrm{R} 2=\mathrm{D} 1 /(\mathrm{G}+\mathrm{D} 1+\mathrm{D} 2)
$$

where the D1 band corresponds to the area of the defect band ca. $1380 \mathrm{~cm}^{-1}, \mathrm{D} 2$ is a Raman band $c a .1620 \mathrm{~cm}^{-1}$ (which appears as a shoulder on the G band), and G is the graphite band ca. $1580 \mathrm{~cm}^{-1}$. Beyssac et al. (2002b) found a 
linear correlation between R2 and metamorphic temperature, which they calibrated using samples from different regional metamorphic belts with well-known pressure and temperature conditions. This method applies for metasediments of pelitic lithology in which carbonaceous material precursor is mainly a kerogen mixed with minor hydrocarbons trapped during diagenesis. They noted that the $\mathrm{R} 2$ parameter variations are significant from 0.0 for pristine graphite to 0.7 for poorly organized carbonaceous material, which limits the applicability of the method to the range $330-650^{\circ} \mathrm{C}$. When $\mathrm{R} 2$ is higher than 0.7 , the corresponding spectrum usually exhibits a very large D1 band, a broad G band $c a .1600 \mathrm{~cm}^{-1}$ (including both G and D2 bands), and a D3 band. The accuracy in the determination of the temperature from this calibration is estimated to be $\pm 50^{\circ} \mathrm{C}$ for temperatures in the range $330-650^{\circ} \mathrm{C}$. This correlation is given by

$$
\mathrm{T}\left({ }^{\circ} \mathrm{C}\right)=-445 \mathrm{R} 2+641
$$

This function was based on Raman analysis of 54 samples representative of high-temperature, low-pressure to highpressure, low-temperature metamorphic gradients. This work, as was the case for the work of Rantitsch et al. (2004) and Rahl et al. (2005), was based on studies of carbonaceous samples from Alpine systems, which are relatively young. Further, work by Rahl et al. (2005) extended the reliability of the Raman geothermometer to low-grade metamorphic rocks, to lower metamorphism temperatures, as low as $100^{\circ} \mathrm{C}$.

Archean cherts are composed largely of silica with trace quantities of carbonaceous materials, which thereby lack metamorphic mineral assemblages that record thermal events. Therefore, Raman spectroscopy of carbonaceous materials as a geothermometer could be a useful tool for constraining the thermal history of these rocks and additionally elucidating the syngenicity of the carbon in these cherts.

To date, Raman spectroscopy has not been used to its full potential as a method of geothermometry for delineating the degree of metamorphism undergone by Archean cherts. Two studies have pushed the way forward in this respect. In the investigation of carbonaceous materials from the Onverwacht, Fig Tree Groups (central Barberton greenstone belt, South Africa) and Marble Bar Chert (Pilbara Craton, Western Australia), Tice et al. (2004) used Raman spectroscopy as a geothermometer. Raman microspectroscopy of carbonaceous material in the Onverwacht and Fig Tree groups in the Barberton greenstone belt indicated a relatively low degree of metamorphism. In particular, the stratigraphically continuous Hooggenoeg, Kromberg, and Mendon Formations of the Onverwacht Group, and the overlying Fig Tree Group, were all subjected to temperatures at most equal to those reflected in chlorite-zone shales, that is, between $300-400^{\circ} \mathrm{C}$ (Bucher and Frey, 1994). In addition, samples from the Marble Bar chert of the Pilbara block, Western Australia, were shown to have been heated to the same extent as was discerned for samples from Barberton. Significantly, Tice et al. (2004) concluded that Raman spectra could be used to test the antiquity of putative microfossils in rocks of comparably heated terrains. Any microfossil or carbonaceous material that yields a Raman spectrum without well-developed D and $G$ bands or displays bands that correspond to functional groups of thermally unstable organic compounds is a recent contaminant (e.g., porphyrins or carotenoids, cf. Edwards et al., 2007). Conversely, a Raman spectrum characteristic of metamorphism comparable to that of the surrounding rocks indicates that the carbonaceous material has been in place since the time of maximum heating.

Allwood et al. (2006) investigated the Raman spectra acquired from carbonaceous materials in the Strelley Pool Chert (Pilbara Craton, Western Australia). The purpose of their study was to determine whether primary structural characteristics of organic molecules may have survived to the present day. They used Raman spectral parameters to identify variations in molecular structure of the carbon and determine whether original characteristics of the carbonaceous materials have been completely thermally overprinted, as would be expected during approximately 3.5 billion years of geological history. To the contrary, they found that the molecular structure of the carbonaceous materials varies depending on the sedimentary layer from the sample locality and the inferred original paleoenvironmental setting of that layer, as determined by other geochemical and geological data. Thus, Allwood et al. (2006) argued that the spectral characteristics of the carbonaceous materials reflect original paleoenvironments that varied through time, from warm hydrothermal settings to cooler marine conditions to a return to hydrothermal conditions. Raman spectroscopy also showed that organic matter is present in trace amounts in association with putative stromatolites in the Strelley Pool Chert, which significantly were previously thought to be devoid of organic remains (Allwood et al., 2006). Furthermore, the Raman spectra of kerogen associated with stromatolites indicate lower thermal maturity compared to the kerogen in non-stromatolitic hydrothermal deposits in overlying and underlying rocks. Significantly, this indicates that the stromatolites are not abiotic hydrothermal precipitates-as previously proposed-but were formed in a cooler marine environment that may have been more favorable to life.

\section{Possible Way Forward for Raman Spectroscopy of Archean or Martian Carbonaceous Materials}

Currently, it is not possible to determine the biogenicity of disordered $s p^{2}$ carbonaceous material by Raman spectroscopy. Pasteris and Wopenka (2003) documented that coals and kerogens of an unequivocal biological origin have similar spectra to nonbiological synthetic disordered $s p^{2}$ carbonaceous materials. Additionally, it should be considered that geochemical maturation or metamorphism of almost all naturally occurring organic matter, whether biological or abiological in origin, has been proposed to give rise to similar resultant thermally stable products covalently cross-linked aromatic hydrocarbons and other aromatic subunits that became transformed and condensed through carbonization and graphitization.

Despite the increasing application of Raman spectroscopy to Archean carbonaceous microstructures and astrobiological prospecting, no work has been done on a rigorous structural interrogation between the thermal alteration products of biological and nonbiological organic material to determine whether Raman spectroscopy can reveal subtle changes in spectra acquired from disordered carbonaceous materials. Raman spectra, in general, contain a wealth of valuable in- 
formation pertaining to the physical and chemical properties of molecules and macromolecular complexes. However, it is not always easy to extract such information from the spectra. This is particularly true for complicated macromolecular materials, for example, first-order spectra obtained from $s p^{2}$ disordered carbonaceous materials, which consist of many components. To resolve multiple components expressed as broad overlapping bands, the second derivative, difference spectra, deconvolution, and curve fitting can be undertaken.

Therefore, we propose a new way forward by investigating the second derivative of the carbon first-order spectrum and deconvolution of this region to ascertain a greater structural understanding between the thermal alteration products of biological and nonbiological material. We propose that future work should concentrate on the compilation of a statistically significant spectral data set that consists of the deconvolution of clearly agreed-upon microfossils and abiotic carbonaceous materials that have a reasonable probability of appearing in Archean and martian settings. In addition, we propose the use of multivariate statistical techniques for simplifying complex spectral data and highlighting subtle interrelationships in an effort to distinguish biologically and nonbiologically derived disordered $s p^{2}$ carbonaceous materials with the goal to produce a database that could be useful in determining biogenicity of Archean and martian carbonaceous materials.

Future work will concentrate on the application of chemometrics to a representative database of biological and nonbiological samples. However, to illustrate the point of delineating subtle spectral differences by deconvolution, we will consider the spectral differences between Archean carbonaceous materials with abiotic carbonaceous microfilaments synthesized in the laboratory by annealing amorphous carbon in the presence of cobalt (Marshall and Wilson, 2004) (Fig. 6). At first glance, the line shape in the carbon first-order spectra of the carbonaceous material isolated from the Strelley Pool Chert, Pilbara region, Western Australia, and abiotic filamentous carbon synthesized by Marshall and Wilson (2004) may look very similar, but what happens when the second derivative and subsequent deconvolution are performed?

A technique in which the absorbance, Raman scattering, or other spectral ordinate is differentiated $n$ times with respect to wavenumber or Raman shift produces the $n^{\text {th }}$ derivative spectrum, that is, the spectrum of the $n^{\text {th }}$ derivative of the original spectrum. Derivatives are used to resolve and locate bands in an envelope. The first derivative will emphasize change in slope and enhance resolution, and the second derivative produces a negative peak for each band and shoulder in the original spectrum. The differences in band shape and intensity are highlighted in the second derivative spectrum. The differences between the two spectra are clearer when the second derivative has been undertaken, as is shown in Fig. 7. The second derivative spectra show that the $G$ band is more complex for the spectrum obtained from the abiotic carbon and that the D band is less complex by comparison to the spectrum acquired from the Strelley Pool Chert carbonaceous material.

To unravel these overlapping bands, curve fitting or deconvolution is used to provide rigorous detail of molecular structure. The primary focus on the curve-fitted bands is to determine their assignment, their height, and shapes, in or-

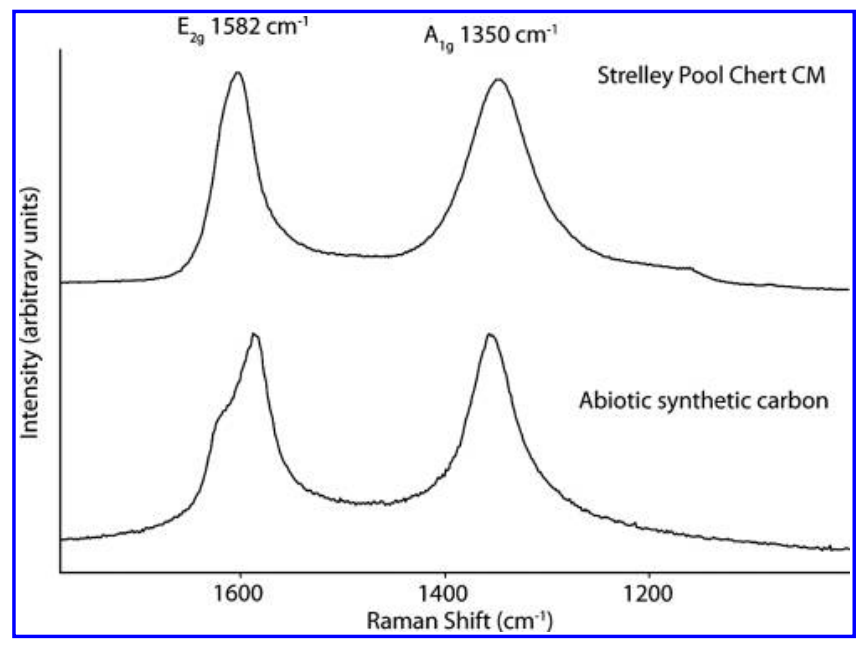

FIG. 6. Comparison stack plot of Raman first-order carbon spectra obtained from isolated kerogen from the Strelley Pool Chert and abiotic synthetic filamentous carbon (fabricated by annealing disordered $s p^{2}$ in the presence of $\mathrm{Co}$, as described in Marshall and Wilson, 2004).

der to provide a better understanding between sample sets. Figure 8 and Table 1 show notable differences that might not have been apparent prior to curve fitting of the carbon firstorder spectra for the two samples. The major differences between the two spectra are positions and nature of the D2 and D4 bands. Significantly, the spectrum acquired from the carbonaceous material isolated from the Strelley Pool Chert has a definite pronounced D4 band, while the D2 band is not so prominent. Furthermore, the ratios derived from the curve fitting show that these materials have a completely different molecular structure, shown by the $\mathrm{L}_{\mathrm{a}}, \mathrm{D} 1 / \mathrm{G}$, and R2 values. By comparison, the aromatic domains are larger (larger $\mathrm{L}_{\mathrm{a}}$ value), and there is less disorder (lower $\mathrm{R} 2$ value) within the carbonaceous network of the abiotic filamentous

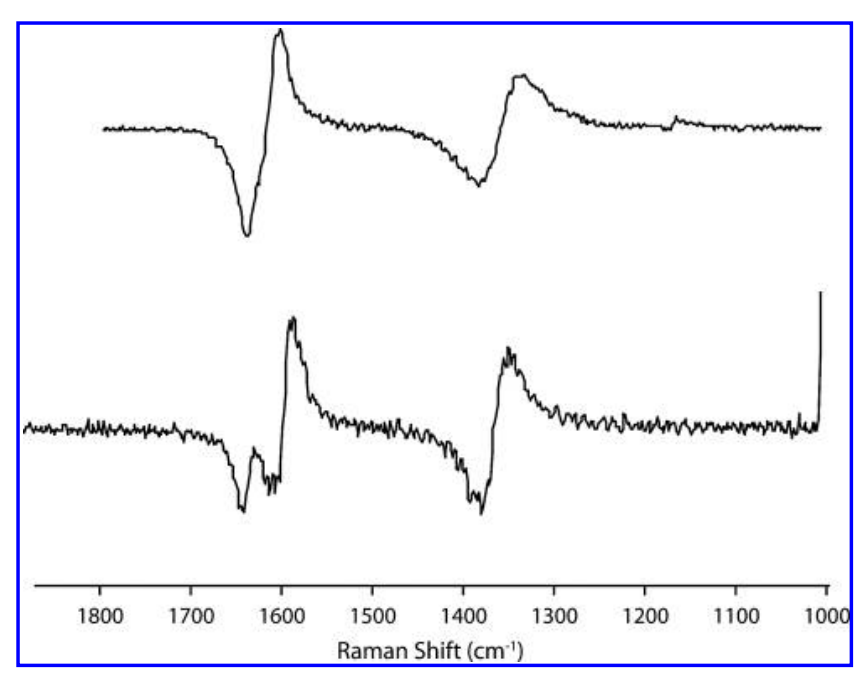

FIG. 7. Comparison stack plot of the second derivative spectra derived from first-order carbon spectra obtained from isolated kerogen from the Strelley Pool Chert and abiotic synthetic filamentous carbon. 


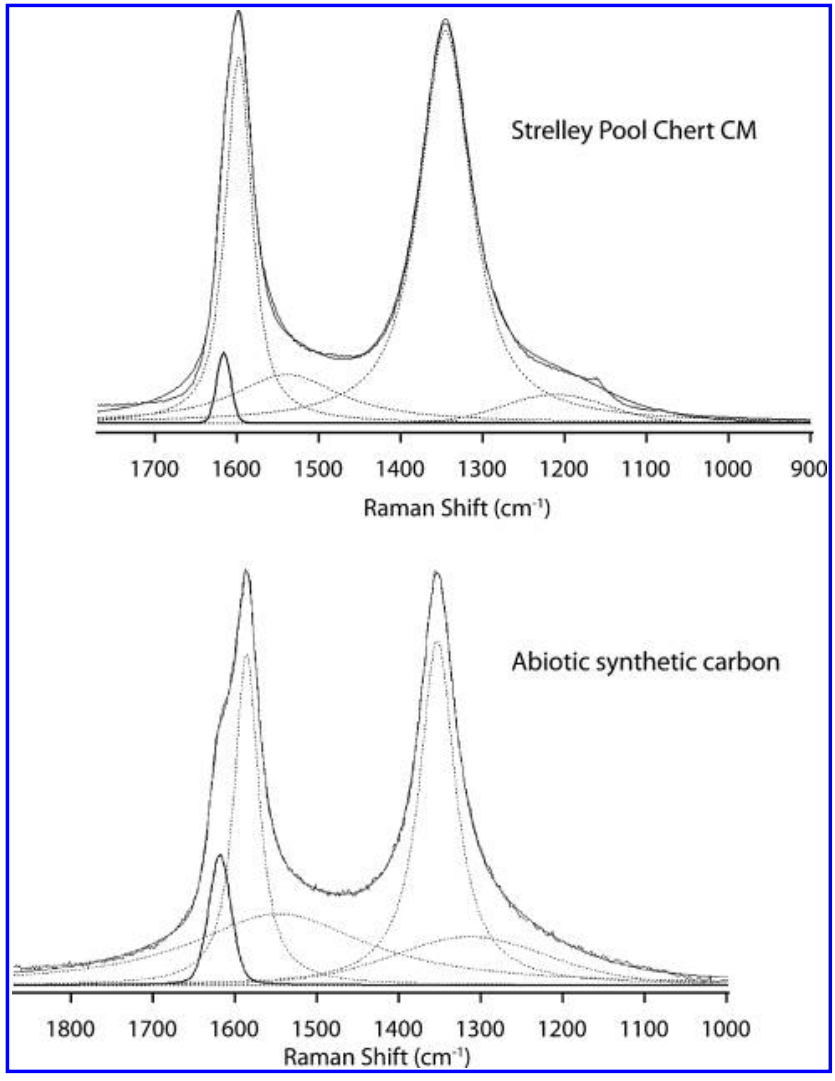

FIG. 8. A comparison plot between the deconvolution of the first-order carbon spectra obtained from isolated kerogen from the Strelley Pool Chert and abiotic synthetic filamentous carbon.

microstructure than that of the carbonaceous material isolated from the Strelley Pool Chert (Table 1). Upon further analysis of the spectra for these two samples, that is, by taking the second derivative and performing deconvolution, the materials can be readily distinguished.

\section{Conclusions}

To date, there has been much controversy in the literature pertaining to the application of Raman spectroscopy to determine a biogenic signal for Archean putative microfossils. Currently, it is considered that nonbiological and biological disordered carbonaceous material display similar Raman spectra. Therefore, the major limitation thus far of using Raman spectroscopy to determine the biogenicity of carbonaceous materials is that bona fide microfossils and putative microfossils yield spectral features indicative of disordered $s p^{2}$ hybridized carbon bonded to carbon. However, Raman spectroscopy of ancient disordered carbonaceous material can be a useful geothermometry tool with which to constrain the thermal history of cherts that lack metamorphic mineral assemblages and to elucidate the syngenicity of the carbon in these cherts.

The Raman spectra of more recent or extant biological samples, however, show the presence of biological functionalized compounds, such as RNA, DNA, amino acids, protein, pigments, and diagenetically altered carotenoids, that are unequivocal for proving a biological origin. Despite the

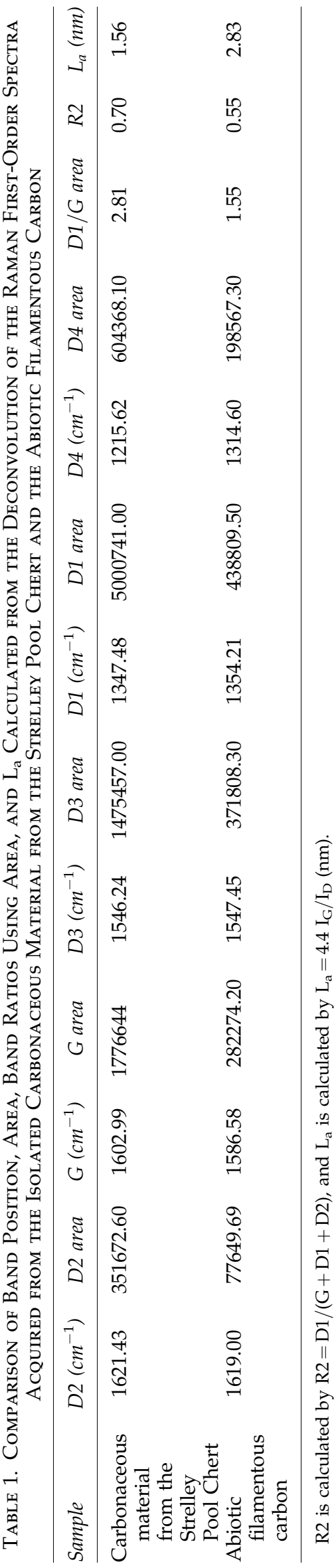


similar nature in disordered $s p^{2}$ carbonaceous material spectra, rigorous structural interrogation between the thermal alteration products of biological and nonbiological organic materials has, to date, not been undertaken. Therefore, we propose a new way forward by investigating the deconvolution of the carbon first-order spectra to build a database of structural parameters that may yield distinguishable characteristics between biogenic and abiogenic carbonaceous material. The impetus to pursue systematic studies of the characteristics of Raman spectra of carbonaceous materials proposed here is that they could lead to the use of this analytical technique as a means to assess the biogenicity of samples of any geological age, on Earth or Mars, that contain organic matter.

\section{Acknowledgments}

C.P.M. would like to thank the Australian Research Council for funding. This work was also supported by a grant MSM0021620855 from the Ministry of Education of the Czech Republic. This manuscript greatly benefited from the comments, suggestions, and ideas of two anonymous reviewers. We would like to thank Dr. Alison Olcott Marshall for re-drafting our figures and reading through the versions of this manuscript.

\section{Abbreviation}

HTT, high-temperature treatments.

\section{References}

Allwood, A.C., Walter, M.R., and Marshall, C.P. (2006) Raman spectroscopy reveals thermal palaeoenvironments of c. 3.5 billion year-old organic matter. Vib. Spectrosc. 41:190-197.

Anderson, R.B. (1984) The Fischer-Tropsch Synthesis, Academic Press, New York.

Appel, P.W.U., Moorbath, S., and Myers, J.S. (2003) Isuasphaera isua (Pflug) revisited. Precambrian Res. 126:309-312.

Awramik, S.M., Schopf, J.W., and Walter, M.R. (1983) Filamentous fossil bacteria from the Archaean of Western Australia. Precambrian Res. 20:357-374.

Bény-Bassez, C. and Rouzaud, J.-N. (1985) Characterization of carbonaceous materials by correlated electron and optical microscopy and Raman microspectroscopy. Scan. Electron. Microsc. 1:119-132.

Beyssac, O., Rouzaud, J.-N., Goffé, B., Brunet, F., and Chopin, C. (2002a) Graphitization in a high-pressure, low-temperature metamorphic gradient: a Raman microspectroscopy and HRTEM study. Contrib. Mineral Petrol. 143:19-31.

Beyssac, O., Goffé, B., Chopin, C., and Rouzaud, J.-N. (2002b) Raman spectra of carbonaceous material in metasediments: a new geothermometer. Journal of Metamorphic Geology 20:859871.

Beyssac, O., Goffe, B., Petitet, J.P., Froigneux, E., Moreau, M., and Rouzaud, J.N. (2003) On the characterization of disordered and heterogeneous carbonaceous materials by Raman spectroscopy. Spectrochim. Acta A Mol. Biomol. Spectrosc. 59:2267-2276.

Bucher, K. and Frey, M. (1994) Petrogenesis of Metamorphic Rocks, Springer-Verlag, New York.

Brasier, M.D., Green, O.R., Jephcoat, A.P., Kleppe, A.T., Van Kranendonk, M.J., Lindsay, J.F., Steele, A., and Grassineau,
N.V. (2002) Questioning the evidence for Earth's oldest fossils. Nature 416:76-81.

Brasier, M.D., Green, O.R., Lindsay, J.F., McLoughlin, N., Steele, A., and Stokes, C. (2005) Critical testing of Earth's oldest putative fossil assemblage from the $\sim 3.5 \mathrm{Ga}$ Apex Chert, Chinaman Creek, Western Australia. Precambrian Res. 140:55102.

Bridgwater, D., Allaart, J.H., Schopf, J.W., Klein, C., Walter, E.S., Strother, P., Knoll, A.H., and Gorman, B.E. (1981) Microfossillike objects from the Archaean of Greenland: a cautionary note. Nature 289:51-53.

Buick, R. (1990) Microfossil recognition in Archean rocks: an appraisal of spheroids and filaments from a 3500 m.y. old chert-barite unit at North Pole, Western Australia. Palaios 5:441-459.

Chadha, S., Manoharan, R., Moenne Loccoz, P., Nelson, W.H., Peticolas, W.L., and Sperry, J.F. (1993) Comparison of the UV resonance Raman-spectra of bacteria, bacteria-cell walls, and ribosomes excited in the deep UV. Appl. Spectrosc. 47: 38-43.

Courreges-Lacoste, G.B., Ahlers, B., and Rull Perez, F. (2007) Combined Raman spectrometer/laser-induced breakdown spectrometer for the next ESA mission to Mars. Spectrochim. Acta A Mol. Biomol. Spectrosc. 68:1023-1028.

Dresselhaus, M.S. and Dresselhaus, G. (1982) Light scattering in graphite intercalation compounds. In Light Scattering in Solids III, edited by M. Cardona and G. Guntherodt, Springer, Berlin, p 187.

Durand, B. (1980) Kerogen: Insoluble Organic Matter from Sedimentary Rocks, Éditions Technip, Paris.

Edwards, H.G.M., Wynn-Williams, D.D., and Villar, S.E.J. (2004) Biological modification of haematite in Antarctic cryptoendolithic communities. I. Raman Spectrosc. 35:470-474.

Edwards, H.G.M., Moody, C.D., Villar, S.E.J., and WynnWilliams, D.D. (2005a) Raman spectroscopic detection of key biomarkers of cyanobacteria and lichen symbiosis in extreme Antarctic habitats: evaluation for Mars lander missions. Icarus 174:560-571.

Edwards, H.G.M., Villar, S.E.J., Parnell, J., Cockell, C.S., and Lee, P. (2005b) Raman spectroscopic analysis of cyanobacterial gypsum halotrophs and relevance for sulfate deposits on Mars. Analyst 130:917-923.

Edwards, H.G.M., Jorge Villar, S.E., Pullan, D., Hofmann, B.A., Hargreaves M.D., and Westall, F. (2007) Morphological biosignatures from relict fossilised sedimentary geological specimens: a Raman spectroscopic study. I. Raman Spectrosc. 38:1352-1361.

Elman, B.S., Dresselhaus, M.S., Dresselhaus, G., Maby, E.W., and Mazurek, H. (1981) Raman scattering from ion-implanted graphite. Phys. Rev. B Condens. Matter Mater. Phys. 24:10271034.

Ferrari, A.C. and Robertson, J. (2000) Interpretation of Raman spectra of disordered and amorphous carbon. Phys. Rev. B Condens. Matter Mater. Phys. 61:14095-14107.

Franklin, R.E. (1951) Crystallite growth in graphitizing and nongraphitizing carbons. Proc. R. Soc. Lond., A, Math. Phys. Sci. 209:196-218.

Jarvis, R.M. and Goodacre, R. (2004) Ultra-violet resonance Raman spectroscopy for the rapid discrimination of urinary tract infection bacteria. FEMS Microbiol. Lett. 232:127-132.

Jehlička, J. and Bény, C. (1992) Application of Raman microspectrometry in the study of structural changes in Precambrian kerogens during regional metamorphism. Org. Geochem. 18:211-213. 
Jehlička, J., and Bény, C.J. (1999) First and second order Raman spectra of natural highly carbonified organic compounds from metamorphic rocks. J. Mol. Struct. 480-481:541-545.

Jehlička, J. and Rouzaud, J.-N. (1990) Organic geochemistry of Precambrian shales and schists (Bohemian Massif, Central Europe). Org. Geochem. 16:865-872.

Jehlička, J., Bény, C., and Rouzaud, J.-N. (1997) Raman microspectrometry of accumulated non-graphitized solid bitumens. I. Raman Spectrosc. 28:717-724.

Knight, D.S. and White, W.B. (1989) Characterization of diamond films by raman-spectroscopy. L. Mater. Res. 4:385-393.

Knoll, A.H. and Barghoorn, E.S. (1977) Archean microfossils showing cell division from the Swaziland system of South Africa. Science 198:396-398.

Krribek, B., Hrabal, J., and Landais, P. (1994) The association of poorly ordered graphite, coke and bitumens in greenschist facies rocks of the Ponikla Group, Lugicum, Czech-Republicthe result of graphitization of various types of carbonaceous matter. Journal of Metamorphic Geology 12:493-503.

Lepot, K., Benzerara, K., Brown, G.E., and Philippot, P. (2008) Microbially influenced formation of 2,724 million years old stromatolites. Nat. Geosci. 1:118-121.

Lespade, P., Al-Jishi, R., and Dresselhaus, M.S. (1982) Model for Raman scattering from incompletely graphitized carbons. Carbon 5:427-431.

Lindsay, J.F., Brasier, M.D., McLoughlin, N., Green, O.R., Fogel, M., Steele, A., and Mertzman, S.A. (2005) The problem of deep carbon and Archean paradox. Precambrian Res. 143:1-22.

Mancinelli, R.L., Faulem, T.F., Landheim, R., and Klovstad, M.R. (2004) Brines and evaporites: analogs for martian life. Adv. Space Res. 33:1244-1246.

Manoharan, R., Ghiamati, E., Dalterio, R.A., Britton, K.A., Nelson, W.H., and Sperry, J.F. (1990) UV resonance Raman spectra of bacteria, bacterial spores, protoplasts and calcium dipicolinate. J. Microbiol. Methods 11:1-15.

Marshall, C.P. and Marshall, A.O. (2010) The potential of Raman spectroscopy for the analysis of diagenetically transformed carotenoids. Philosophical Transactions A, in press.

Marshall, C.P. and Wilson, M.A. (2004) Effects of ball milling and annealing graphite in the presence of cobalt. Carbon 42:2179-2186

Marshall, C.P., Javaux, E.J., Knoll, A.H., and Walter, M.R. (2005) Combined micro-Fourier Transform Infrared (FTIR) spectroscopy and micro-Raman spectroscopy of Proterozoic acritarchs: a new approach to palaeobiology. Precambrian Res. 138:208224.

Marshall, C.P., Carter, E.A., Leuko, S., and Javaux, E.J. (2006) Vibrational spectroscopy of extant and fossil microbes: relevance for the astrobiological exploration of Mars. Vib. Spectrosc. 41:182-189.

Marshall, C.P., Love, G.D., Snape, C.E., Hill, A.C., Allwood, A.C., Walter, M.R., Van Kranendonk, M.J., Bowden, S.A., Sylva, S.P., and Summons, R.E. (2007a) Structural characterization of kerogen in $3.4 \mathrm{Ga}$ Archaean cherts from the Pilbara Craton, Western Australia. Precambrian Res. 155:123.

Marshall, C.P., Leuko, S., Coyle, C.M., Walter, M.R., Burns, B.P., and Neilan, B.A. (2007b) Carotenoid analysis of halophilic archaea by resonance Raman spectroscopy. Astrobiology 7:631643.

McCollom, T.M. and Seewald, J.S. (2006) Carbon isotope composition of organic compounds produced by abiotic synthesis under hydrothermal conditions. Earth Planet. Sci. Lett. 243: 74-84.
Mernagh, T.P., Cooney, R.P., and Johnson, R.A. (1984) Raman spectra of Graphon carbon black. Carbon 22:39-42.

Mojzsis, S.J., Arrhenius, G., McKeegan, K.D., Harrison, T.M., Nutman, A.P., and Friend, C.R.L. (1996) Evidence for life on Earth before 3,800 million years ago. Nature 385:5559 .

Nakamizo M., Kammereck R., and Walker, P.L., Jr. (1974) Laser Raman studies on carbons. Carbon 12:259-267.

Naumann, D., Helm, D., and Labischinski, H. (1991a) Microbiological characterizations by FT-IR spectroscopy. Nature 351:81-82.

Naumann, D., Helm, D., Labischinski, H., and Giesbrecht, P. (1991b) UV resonance Raman spectroscopic detection and identification of bacteria and other microorganisms. In Modern Techniques for Rapid Microbiological Analysis, edited by W.H. Nelson, VCH Publisher, New York, pp 43-96.

Pasteris J.D. and Wopenka B. (1991) Raman-spectra of graphite as indicators of degree of metamorphism Can. Mineral. 29:143153.

Pasteris, J.D. and Wopenka, B. (2002) Images of the Earth's earliest fossils? Nature 420:476-477.

Pasteris, J.D. and Wopenka, B. (2003) Necessary, but not sufficient: Raman identification of disordered carbon as a signature of ancient life. Astrobiology 3:727-738.

Pflug, H.D. (1984) Die Spur des Lebens, Springer, Berlin.

Pflug, H.D. and Jaeschke-Boyer, H. (1979) Combined structural and chemical analysis of 3,800-Myr-old microfossils. Nature 280:483-486.

Pocsik, I., Hundhausen, M., Koos, M., and Ley, L. (1998) Origin of the D peak in the Raman spectrum of microcrystalline graphite. Journal of Non-Crystalline Solids 227-230: 1083-1086.

Rahl, J.M., Anderson, K.M., Brandon, M.T., and Fassoulas, C. (2005) Raman spectroscopic carbonaceous material thermometry of low-grade metamorphic rocks: calibration and application to tectonic exhumation in Crete, Greece. Earth Planet. Sci. Lett. 240:339-354.

Rantitsch, G., Grogger, W., Teichert, C., Ebner, F., Hofer, C., Maurer, E.M., Schaffer, B., and Toth, M. (2004) Conversion of carbonaceous material to graphite within the Greywacke Zone of the Eastern Alps. International Journal of Earth Sciences 936:959-973.

Rasmussen, B. (2000) Filamentous microfossils in a 3250-millionyear-old volcanogenic massive sulphide deposit. Nature 405:676-679.

Roedder, E. (1981) Are the 3,800-Myr-old Isua objects microfossils, limonite-stained fluid inclusions, or neither? Nature 293:459-462.

Rosing, M.T. (1999) ${ }^{13}$ C-depleted carbon microparticles in $>3700$-Ma sea-floor sedimentary rocks from West Greenland. Science 283:674-676.

Rouzaud, J.N. and Oberlin, A. (1989) Structure and microtexture and optical-properties of anthracene and saccharose-based carbons. Carbon 27:517-529.

Schidlowski, M. (2001) Carbon isotopes as biogeochemical reorders of life over $3.8 \mathrm{Ga}$ of Earth history: evolution of a concept. Precambrian Res. 106:117-134.

Schopf, J.W. (1993) Microfossils of the Early Archean Apex Chert: new evidence of the antiquity of life. Science 260:640646.

Schopf, J.W. and Walter, M.R. (1983) Archean microfossils: new evidence of ancient microbes. In Earth's Earliest Biosphere: Its Origin and Evolution, edited by J.W. Schopf, Princeton University Press, Princeton, pp 214-239. 
Schopf, J.W., Kudryavtsev, A.B., Agresti, D.G., Wdowiak, T.J., and Czaja, A.D. (2002) Laser-Raman imagery of Earth's earliest fossils. Nature 416:73-76.

Storrie-Lombardi, M.C., Hug, W.F., McDonald, G.D., Tsapin, A.I., and Nealson, K.H. (2001) Hollow cathode ion lasers for deep ultraviolet Raman spectroscopy and fluorescence imaging. Rev. Sci. Instrum. 72:4452-4459.

Strazzulla, G., Baratta, G.A., and Palumbo, M.E. (2001) Vibrational spectroscopy of ion-irradiated ices. Spectrochim. Acta A Mol. Biomol. Spectrosc. 57:825-842.

Summons, R.E. and Walter, M.R. (1990) Molecular fossils and microfossils of prokaryotes and protists from Proterozoic sediments. Am. J. Sci. 290-A:212-244.

Tarcea, N., Harz, M., Rosch, P., Frosch, T., Schmitt, M., Thiele, H., Hochleitner, R., and Popp, J. (2007) UV Raman spectroscopy-a technique for biological and mineralogical in situ planetary studies. Spectrochim. Acta A Mol. Biomol. Spectrosc. 68:1029-1035.

Tice, M.M., Bostick, B.C., and Lowe, D.R. (2004) Thermal history of the 3.5-3.2 Ga Onverwacht and Fig Tree Groups, Barberton greenstone belt, South Africa, inferred by Raman microspectroscopy of carbonaceous material. Geology 32:37-40.

Toporski, J. and Steele, A. (2007) Observations from a 4-year contamination study of a sample depth profile through martian meteorite Nakhla. Astrobiology 7:389-401.

Tuinstra, F. and Koenig, J.L. (1970) Raman spectrum of graphite. L. Chem. Phys. 53:1126-1130.

Ueno, Y., Isozaki, Y., Yurimoto, H., and Maruyama, S. (2001a) Carbon isotopic signatures of individual Archaean microfossils (?) from Western Australia. International Geology Review 43:196-212.

Ueno, Y., Isozaki, Y., Yurimoto, H., and Maruyama, S. (2001b) Early Archean (ca. 3.5) microfossils and ${ }^{13} \mathrm{C}$-depleted carbonaceous matter in the North Pole area, Western Australia. Field occurrence and geochemistry. In Geochemistry and the Origin of Life, edited by S. Nakashima, S. Maruyama, A. Brack, and B.F. Windley, Universal Academy Press, Tokyo, pp 203236.

Ueno, Y., Yurimoto, H., Yoshioka, H., Komiya, T., and Maruyama, S. (2002) Ion microprobe analysis of graphite from $c a$. 3.8 Ga meta-sediments, Isua supracrustal belt, West Greenland: relationship between metamorphism and carbon isotopic composition. Geochim. Cosmochim. Acta 45:1257-1268.

Ueno, Y., Yoshioka, H., Maruyama, S., and Isozaki, Y. (2004) Carbon isotopes and petrography of kerogens in $\sim 3.5 \mathrm{Ga}$ hydrothermal silica dikes in the North Pole area, Western Australia. Geochim. Cosmochim. Acta 68:573-589.

Ueno, Y., Yamada, K., Yoshida, N., Maruyama, S., and Isozaki, Y. (2006) Biosignatures and abiotic constraints on early life. Nature 440:516-519.

van Zuilen, M.A., Mathew, K., Wopenka, B., Lepland, A., Marti, K., and Arrhenius, A. (2005) Nitrogen and argon isotopic signatures in graphite from the 3.8-Ga-old Isua Supracrustal Belt, southern West Greenland. Geochim. Cosmochim. Acta 69:1241-1252.

van Zuilen, M.A., Chaussidon, M., Rollion-Bard, C., and Marty, B. (2007) Carbonaceous cherts of the Barberton greenstone belt, South Africa: isotopic, chemical and structural characteristics of individual microstructures. Geochim. Cosmochim. Acta 71:655-669.

Vidano, R.P., Fischbach, D.B., Wilis, J.L., and Loehr, T.M. (1981) Observation of Raman band shifting with excitation wave- length for carbons and graphites. Solid State Communications 39:341-344.

Villar, S.E.J. and Edwards, H.G.M. (2006) Raman spectroscopy in astrobiology. Anal. Bioanal. Chem. 384:100-113.

Villar, S.E.J., Edwards, H.G.M., and Worland, M.R. (2005) Comparative evaluation of Raman spectroscopy at different wavelengths for extremophile exemplars. Orig. Life Evol. Biosph. 35:489-506.

Walsh, M.M. and Lowe, D.R. (1985) Filamentous microfossils from the 3,500-Myr old Onverwacht Group, Barberton Mountain Land, South Africa. Nature 314:530-532.

Wang, A., Dhamelincourt, P., Dubessy, J., Guerard, D., Landais, P., and Lelaurain, M. (1989) Characterization of graphite alteration in an uranium deposit by micro-Raman spectroscopy, X-ray diffraction, transmission electron-microscopy and scanning electron-microscopy. Carbon 27:209-218.

Wang, A., Haskin, L.A., Lane, A.L., Wdowiak, T.J., Squyres, S.T., Wilson, R.J., Hovland, L.E., Manatt, K.S., Raouf, N., and Smith, C.D. (2003) Development of the Mars microbeam Raman spectrometer (MMRS). J. Geophys. Res. 108:1-18.

Westall, F., de Wit, M.J., Dann, J., van der Gaast, S., de Ronde, C.E.J., and Gerneke, D. (2001) Early Archean fossil bacteria and biofilms in hydrothermally influenced sediments from the Barberton greenstone belt, South Africa. Precambrian Res. 106:93-116.

Westall, F., de Ronde, C.E.J., Southam, G., Grassineau, N., Colas, M., Cockell, C., and Lammer, H. (2006) Implications of a 3.472-3.333 Gyr-old subaerial microbial mat from the Barberton greenstone belt, South Africa for the UV environmental conditions on the early Earth. Philos. Trans. R. Soc. Lond., B, Biol. Sci. 361:1857-1875.

Wopenka, B. and Pasteris, J.D. (1993) Structural characterization of kerogens to granulite-facies graphite; applicability of Raman microprobe spectroscopy. Am. Mineral. 78:533-557.

Wu, Q., Hamilton, T., Nelson, W.H., Elliott, S., Sperry, J.F., and Wu, M. (2001) UV Raman spectral intensities of E. coli and other bacteria excited at 228.9, 244.0, and $248.2 \mathrm{~nm}$. Anal. Chem. 73:3432-3440.

Wynn-Williams, D.D. and Edwards, H.G.M. (2000a) Proximal analysis of regolith habitats and protective biomolecules in situ by laser Raman spectroscopy: overview of terrestrial Antarctic habitats and Mars analogs. Icarus 144:486-503.

Wynn-Williams, D.D. and Edwards, H.G.M. (2000b) Antarctic ecosystems as models for extraterrestrial surface habitats. Planet. Space Sci. 48:1065-1075.

Yui, T.F., Huang, E., and Xu, J. (1996) Raman spectrum of carbonaceous material: a possible metamorphic grade indicator for low-grade metamorphic rocks. Journal of Metamorphic Geology 14:115-124.

Address correspondence to: Craig P. Marshall Department of Geology The University of Kansas Lawrence, Kansas 66045-7613 USA

E-mail: cpmarshall@ku.edu

Submitted 9 February 2009

Accepted 28 December 2009 



\section{This article has been cited by:}

1. Alison Olcott Marshall, Craig P. Marshall. 2015. Vibrational spectroscopy of fossils. Palaeontology 58:10.1111/pala.2015.58.issue-2, 201-211. [CrossRef]

2. Liam V. Harris, Melissa McHugh, Ian B. Hutchinson, Richard Ingley, Cédric Malherbe, John Parnell, Alison Olcott Marshall, Howell G. M. Edwards. 2015. Avoiding misidentification of bands in planetary Raman spectra. Journal of Raman Spectroscopy $\mathrm{n} / \mathrm{a}-\mathrm{n} / \mathrm{a}$. [CrossRef]

3. H. G. M. Edwards, I. B. Hutchinson, R. Ingley, J. Jehli ka. 2014. Biomarkers and their Raman spectroscopic signatures: a spectral challenge for analytical astrobiology. Philosophical Transactions of the Royal Society A: Mathematical, Physical and Engineering Sciences 372, 20140193-20140193. [CrossRef]

4. C. P. Marshall, A. O. Marshall. 2014. Raman spectroscopy as a screening tool for ancient life detection on Mars. Pbilosophical Transactions of the Royal Society A: Mathematical, Physical and Engineering Sciences 372, 20140195-20140195. [CrossRef]

5. P. Vitek, J. Jehli ka, H. G. M. Edwards, I. Hutchinson, C. Ascaso, J. Wierzchos. 2014. Miniaturized Raman instrumentation detects carotenoids in Mars-analogue rocks from the Mojave and Atacama deserts. Pbilosophical Transactions of the Royal Society A: Mathematical, Physical and Engineering Sciences 372, 20140196-20140196. [CrossRef]

6. I. B. Hutchinson, R. Ingley, H. G. M. Edwards, L. Harris, M. McHugh, C. Malherbe, J. Parnell. 2014. Raman spectroscopy on Mars: identification of geological and bio-geological signatures in Martian analogues using miniaturized Raman spectrometers. Philosophical Transactions of the Royal Society A: Mathematical, Physical and Engineering Sciences 372, 20140204-20140204. [CrossRef]

7. Danny Lambert, Cyril Muehlethaler, Line Gueissaz, Geneviève Massonnet. 2014. Raman analysis of multilayer automotive paints in forensic science: measurement variability and depth profile. Journal of Raman Spectroscopy 45:10.1002/jrs.v45.11-12, 1285-1292. [CrossRef]

8. Ian B. Hutchinson, John Parnell, Howell G.M. Edwards, Jan Jehlicka, Craig P. Marshall, Liam V. Harris, Richard Ingley. 2014. Potential for analysis of carbonaceous matter on Mars using Raman spectroscopy. Planetary and Space Science 103, 184-190. [CrossRef]

9. Abby L. Glauser, Carla J. Harper, Thomas N. Taylor, Edith L. Taylor, Craig P. Marshall, Alison Olcott Marshall. 2014. Reexamination of cell contents in Pennsylvanian spores and pollen grains using Raman spectroscopy. Review of Palaeobotany and Palynology 210, 62-68. [CrossRef]

10. T. N. Moroz, S. V. Goryainov, N. P. Pokhilenko, N. M. Podgornykh. 2014. Crystalline and amorphous matter in the Chelyabinsk meteorite: Evidence from Raman spectroscopy. Doklady Earth Sciences 457, 831-834. [CrossRef]

11. Cheng Huang, YiMing Gong. 2014. Phosphatic microspherules and their geobiological implications from the Frasnian-Famennian transition at the Yangdi section, Guilin, South China. Science China Earth Sciences 57, 943-956. [CrossRef]

12. Nils K. Lünsdorf, Istvan Dunkl, Burkhard C. Schmidt, Gerd Rantitsch, Hilmar von Eynatten. 2014. Towards a Higher Comparability of Geothermometric Data obtained by Raman Spectroscopy of Carbonaceous Material. Part I: Evaluation of Biasing Factors. Geostandards and Geoanalytical Research 38, 73-94. [CrossRef]

13. Lenize Fernandes Maia, Beatriz Grosso Fleury, Bruno Gualberto Lages, Joel Christopher Creed, Luiz Fernando Cappa de OliveiraNew Strategies for Identifying Natural Products of Ecological Significance from Corals 313-349. [CrossRef]

14. Craig P. Marshall, Alison Olcott Marshall. 2013. Raman Hyperspectral Imaging of Microfossils: Potential Pitfalls. Astrobiology 13:10, 920-931. [Abstract] [Full Text HTML] [Full Text PDF] [Full Text PDF with Links]

15. Didier Gourier, Olivier Delpoux, Laurent Binet, Hervé Vezin. 2013. Nuclear Magnetic Biosignatures in the Carbonaceous Matter of Ancient Cherts: Comparison with Carbonaceous Meteorites. Astrobiology 13:10, 932-947. [Abstract] [Full Text HTML] [Full Text PDF] [Full Text PDF with Links]

16. Alison Olcott Marshall, Craig P. Marshall. 2013. Field-Based Raman Spectroscopic Analyses of an Ordovician Stromatolite. Astrobiology 13:9, 814-820. [Abstract] [Full Text HTML] [Full Text PDF] [Full Text PDF with Links]

17. Bruce M. Rothschild, Larry D. Martin, Brendan Anderson, Alison Olcott Marshall, Craig P. Marshall. 2013. Raman spectroscopic documentation of Oligocene bladder stone. Naturwissenschaften . [CrossRef]

18. F. Foucher, G. Lopez-Reyes, N. Bost, F. Rull-Perez, P. Rüßmann, F. Westall. 2013. Effect of grain size distribution on Raman analyses and the consequences for in situ planetary missions. Journal of Raman Spectroscopy 44:10.1002/jrs.v44.6, 916-925. [CrossRef]

19. Alison Olcott Marshall, Jan Jehlicka, Jean-Noel Rouzaud, Craig P. Marshall. 2013. Multiple generations of carbonaceous material deposited in Apex chert by basin-scale pervasive hydrothermal fluid flow. Gondwana Research . [CrossRef] 
20. Susana Jorge-Villar, Howell Edwards. 2013. Microorganism Response to Stressed Terrestrial Environments: A Raman Spectroscopic Perspective of Extremophilic Life Strategies. Life 3, 276-294. [CrossRef]

21. Frédéric Foucher, Frances Westall. 2013. Raman Imaging of Metastable Opal in Carbonaceous Microfossils of the 700-800 Ma Old Draken Formation. Astrobiology 13:1, 57-67. [Abstract] [Full Text HTML] [Full Text PDF] [Full Text PDF with Links]

22. D.M. Bower, A. Steele, M.D. Fries, L. Kater. 2013. Micro Raman Spectroscopy of Carbonaceous Material in Microfossils and Meteorites: Improving a Method for Life Detection. Astrobiology 13:1, 103-113. [Abstract] [Full Text HTML] [Full Text PDF] [Full Text PDF with Links]

23. B. Kremer, K. Owocki, A. Królikowska, B. Wrzosek, J. Kazmierczak. 2012. Mineral microbial structures in a bone of the Late Cretaceous dinosaur Saurolophus angustirostris from the Gobi Desert, Mongolia - a Raman spectroscopy study. Palaeogeography, Palaeoclimatology, Palaeoecology 358-360, 51-61. [CrossRef]

24. J. D. Schiffbauer, A. F. Wallace, J. L. Hunter, M. Kowalewski, R. J. Bodnar, S. Xiao. 2012. Thermally-induced structural and chemical alteration of organic-walled microfossils: an experimental approach to understanding fossil preservation in metasediments. Geobiology 10:10.1111/gbi.2012.10.issue-5, 402-423. [CrossRef]

25. Barbara Cavalazzi, Roberto Barbieri, Sherry L. Cady, Annette D. George, Salvatore Gennaro, Frances Westall, Alberto Lui, Roberto Canteri, Angelo Pio Rossi, Gian Gabriele Ori, Kamal Taj-Eddine. 2012. Iron-framboids in the hydrocarbon-related Middle Devonian Hollard Mound of the Anti-Atlas mountain range in Morocco: Evidence of potential microbial biosignatures. Sedimentary Geology 263-264, 183-193. [CrossRef]

26. David K. Muirhead, John Parnell, Colin Taylor, Stephen A. Bowden. 2012. A kinetic model for the thermal evolution of sedimentary and meteoritic organic carbon using Raman spectroscopy. Journal of Analytical and Applied Pyrolysis 96, 153-161. [CrossRef]

27. Lewis R. DARTNELL, Manish R. PATEL, Michael C. STORRIE-LOMBARDI, John M. WARD, Jan-Peter MULLER. 2012. Experimental determination of photostability and fluorescence-based detection of PAHs on the Martian surface. Meteoritics \& Planetary Science 47:10.1111/maps.2012.47.issue-5, 806-819. [CrossRef]

28. Lewis R. Dartnell, Kristian Page, Susana E. Jorge-Villar, Gary Wright, Tasnim Munshi, Ian J. Scowen, John M. Ward, Howell G. M. Edwards. 2012. Destruction of Raman biosignatures by ionising radiation and the implications for life detection on Mars. Analytical and Bioanalytical Chemistry . [CrossRef]

29. Alison Olcott Marshall, Julienne R. Emry, Craig P. Marshall. 2012. Multiple Generations of Carbon in the Apex Chert and Implications for Preservation of Microfossils. Astrobiology 12:2, 160-166. [Abstract] [Full Text HTML] [Full Text PDF] [Full Text PDF with Links]

30. S. Danise, B. Cavalazzi, S. Dominici, F. Westall, S. Monechi, S. Guioli. 2012. Evidence of microbial activity from a shallow water whale fall (Voghera, northern Italy). Palaeogeography, Palaeoclimatology, Palaeoecology 317-318, 13-26. [CrossRef]

31. Bénédicte Ménez, Valerio Pasini, Daniele Brunelli. 2012. Life in the hydrated suboceanic mantle. Nature Geoscience . [CrossRef]

32. Barbara Kremer, Michael Bauer, Robert W. Stark, Norbert Gast, Wladyslaw Altermann, Hans-Jürgen Gursky, Wolfgang M. Heckl, Józef Kazmierczak. 2012. Laser-Raman and atomic force microscopy assessment of the chlorococcalean affinity of problematic microfossils. Journal of Raman Spectroscopy 43:10.1002/jrs.v43.1, 32-39. [CrossRef]

33. P. Vandenabeele, J. Jehlička, P. Vítek, H.G.M. Edwards. 2011. On the definition of Raman spectroscopic detection limits for the analysis of biomarkers in solid matrices. Planetary and Space Science . [CrossRef]

34. J. Jehlička, P. Vandenabeele, H.G.M. Edwards. 2011. Discrimination of zeolites and beryllium containing silicates using portable Raman spectroscometric equipment with near-infrared excitation. Spectrocbimica Acta Part A: Molecular and Biomolecular Spectroscopy . [CrossRef]

35. Craig P. Marshall, Alison Olcott Marshall. 2011. Hematite and carbonaceous materials in geological samples: A cautionary tale. Spectrocbimica Acta Part A: Molecular and Biomolecular Spectroscopy 80, 133-137. [CrossRef]

36. Charles S. Cockell, Laura C. Kelly, Stephen Summers, Viggo Marteinsson. 2011. Following the Kinetics: Iron-Oxidizing Microbial Mats in Cold Icelandic Volcanic Habitats and Their Rock-Associated Carbonaceous Signature. Astrobiology 11:7, 679-694. [Abstract] [Full Text HTML] [Full Text PDF] [Full Text PDF with Links]

37. Barbara Cavalazzi, Frances Westall, Sherry L. Cady, Roberto Barbieri, Frédéric Foucher. 2011. Potential Fossil Endoliths in Vesicular Pillow Basalt, Coral Patch Seamount, Eastern North Atlantic Ocean. Astrobiology 11:7, 619-632. [Abstract] [Full Text HTML] [Full Text PDF] [Full Text PDF with Links]

38. Leszek Marynowski, Michał Rakociński, Ewelina Borcuch, Barbara Kremer, Brian A. Schubert, A. Hope Jahren. 2011. Molecular and petrographic indicators of redox conditions and bacterial communities after the $\mathrm{F} / \mathrm{F}$ mass extinction (Kowala, Holy Cross Mountains, Poland). Palaeogeography, Palaeoclimatology, Palaeoecology 306, 1-14. [CrossRef] 
39. Craig P. Marshall, Julienne R. Emry, Alison Olcott Marshall. 2011. Haematite pseudomicrofossils present in the 3.5-billion-yearold Apex Chert. Nature Geoscience 4, 240-243. [CrossRef]

40. Dina M. Bower. 2011. Micro-Raman spectroscopic investigations of mineral assemblages in parallel to bedding laminae in $2.9 \mathrm{Ga}$ sandstones of the Pongola Supergroup, South Africa. Journal of Raman Spectroscopy n/a-n/a. [CrossRef]

41. Howell G. EdwardsFourier Transform Raman Instrumentation 1-24. [CrossRef]

42. Olivier Beyssac, Michele LazzeriApplication of Raman spectroscopy to the study of graphitic carbons in the Earth Sciences 415-454. [CrossRef] 